\title{
ECOLOGICAL PHYSIOLOGY OF MAMMALS
}

\section{IN ARGENTINA: A DEVELOPING AND PROMISING FIELD}

\author{
Facundo Luna ${ }^{1}$, Ana Paula Cutrera ${ }^{1}$ and Roxana R. Zenuto ${ }^{1}$ \\ ${ }^{1}$ Grupo de Investigación Ecología Fisiológica y del Comportamiento, IIMyC (CONICET, UNMdP), Buenos Aires, Argentina. \\ [Correspondence: Facundo Luna <fluna@mdp.edu.ar>]
}

\begin{abstract}
Ecological physiology is a discipline that occurs at the intersection of comparative physiology, ecology and evolution, with emphasis on patterns and processes by which physiological diversity arises and persists in nature. Here, our objective is to review articles on ecological physiology that use mammals from Argentina as study organisms, including studies conducted in both field and laboratory settings over the last 25 years. Variation in physiological responses is considered in relation to changes in ecological conditions, focusing on energetics, ecological endocrinology and ecoimmunology. Of these topics, studies related to energy acquisition and expenditure are the most numerous, with a less substantive body of research available for ecological endocrinology and ecoimmunology due to their their more recent development in Argentina. The number of species studied is limited and most are rodents, likely reflecting the difficulties of monitoring physiological parameters in nature as well as implementing controlled studies in captivity. Understanding the roles of life history, habitat, and phylogeny in shaping the physiological responses of animals to environmental conditions requires additional studies that consider more species from different clades of mammals and that include data collected over larger geographical and temporal scales. We anticipate that such studies of physiology will substantially expand our knowledge of mammalian biology while also resulting in improved conservation of these animals and a more effective management of South American environments.
\end{abstract}

RESUMEN. Fisiología ecológica de mamíferos en Argentina: un campo en desarrollo y prometedor. La fisiología ecológica es una disciplina que surge de la conjunción entre la fisiología comparada, la ecología y la evolución, centrándose en los patrones y procesos que explican el surgimiento y mantenimiento de la diversidad fisiológica en la naturaleza. En el presente trabajo, nuestro objetivo es realizar una revisión de los artículos del campo de la fisiología ecológica que emplean mamíferos de Argentina como organismos de estudio, incluyendo estudios realizados tanto en el campo como en el laboratorio en los últimos 25 anos. La variación en las respuestas fisiológicas es considerada en relación a cambios en las condiciones ecológicas, centrándonos en la energética, la endocrinología ecológica y la ecoinmunología. De estos tres temas, los estudios relacionados con la adquisición y el gasto de energía son los más numerosos, con menor cantidad de trabajos en el área de la endocrinología ecológica y, en especial, en la ecoinmunología, dado el desarrollo más reciente de estas disciplinas en Argentina. El número de especies estudiadas es limitado y la mayoría de ellos son roedores, lo cual probablemente sea el reflejo de las dificultades que representa monitorear parámetros fisiológicos en la naturaleza, así como implementar estudios controlados en cautiverio. Comprender los roles de la historia de vida, el hábitat y la filogenia en dar forma a las respuestas fisiológicas de los animales a las condiciones ambientales requiere estudios adicionales que consideren más especies de diferentes clados de mamíferos y que incluyan datos recolectados en escalas geográficas y temporales más extensas. Al lograr estos objetivos, esperamos un impacto importante en la expansión de nuestro conocimiento científico, la conservación de nuestra fauna local y una gestión ambiental más eficiente. 
RESUMO. Fisiologia ecológica de mamíferos na Argentina: um campo em desenvolvimento e promissor. A fisiologia ecológica é uma disciplina que ocorre na interseção da fisiologia comparada, ecologia e evolução, com ênfase em padrões e processos pelos quais a diversidade fisiológica surge e persiste na natureza. Aqui, nosso objetivo é revisar artigos sobre fisiologia ecológica que utilizem mamíferos da Argentina como organismos de estudo, incluindo estudos realizados tanto em campo quanto em laboratório nos últimos 25 anos. A variação nas respostas fisiológicas é considerada em relação às mudanças nas condições ecológicas, com foco em energética, endocrinologia ecológica e ecoimunologia. Desses tópicos, os estudos relacionados à aquisição e gasto de energia são os mais numerosos, com um corpo de pesquisa menos substantivo disponível para endocrinologia ecológica e ecoimunologia, devido ao seu desenvolvimento mais recente na Argentina. O número de espécies estudadas é limitado e a maioria é de roedores, provavelmente refletindo as dificuldades de monitorar os parâmetros fisiológicos da natureza, além de implementar estudos controlados em cativeiro. A compreensão dos papéis da história de vida, habitat e filogenia na formação das respostas fisiológicas dos animais às condições ambientais exige estudos adicionais que considerem mais espécies de diferentes espécies de mamíferos e que incluam dados coletados em escalas geográficas e temporais maiores. Prevemos que esses estudos de fisiologia expandirão substancialmente nosso conhecimento da biologia de mamíferos e, ao mesmo tempo, resultarão em melhor conservação desses animais e em um gerenciamento mais eficaz dos ambientes sul-americanos.

Key words: ecological endocrinology, ecological immunology, energy metabolism, thermoregulation.

Palabras clave: endocrinología ecológica, inmunología ecológica, metabolismo energético, termorregulación.

Palabras-chaves: endocrinologia ecológica, imunologia ecológica, metabolismo energético, termorregulação.

\section{INTRODUCTION}

Ecological physiology has received considerable attention in recent years due to a growing number of empirical and theoretical studies. The overall goal of this discipline is to evaluate the function of physiological mechanisms in the contexts of ecology and evolution. Multiple studies have attempted to determine how differences in physiological mechanisms influence the distribution and abundance of organisms in space and time (Bozinovic et al. 2011). By exploring the processes by which such mechanisms arise and are maintained, ecological physiology seeks to understand how physiological parameters are shaped by natural selection ( $\mathrm{McNab}$ 2002; Bozinovic 2003; Withers et al. 2016).

Ecological physiology emerged in the early $1960 \mathrm{~s}$ as an integrative, conceptually driven offshoot of comparative physiology. Studies conducted during the 1960s and 1970s established the importance of diversity in physiological mechanisms as a means of responding to different environmental conditions (see Schmidt-Nielsen 1997). The mid 1980s marked a crucial junction for this discipline, due to the incorporation of a phylogenetic, or evolutionary perspective into physiological analyses (Felsenstein, 1985). Today, research in ecological physiology draws upon these foundations to examine the adap- tive and functional importance of physiological diversity; although reductionist analyses of the physical and chemical bases for physiological responses are important, they are only part of the larger ecological and evolutionary contexts in which animals respond to environmental conditions ( $\mathrm{McNab} 2002)$.

Here, we evaluate the current status of research in ecological physiology, focusing on studies of wild mammals from Argentina that have been conducted over the last 25 years. Within this taxonomic scope, we consider multiple aspects of physiological response to changes in ecological conditions. Because ecological physiology is necessarily an integrative discipline, our review touches on an array of topics, with emphasis on energetics, water balance, endocrinology, and immunology. The research reviewed here includes studies of both free-living and captive animals, with emphasis on the complementarity of data collected in these two contexts. Because ecological physiology is a relatively new discipline in Argentina, this effort encompasses the vast majority of studies conducted in mammals over the last 25 years. Throughout this review, we seek to identify topics particularly in need of further investigation and we highlight taxa that appear to be well suited to such research. Our goal is to stimulate exciting new studies of mammalian ecophysiology 
that will carry this discipline through the next quarter century and beyond.

\section{ENERGETICS}

Ecological physiology provides an important bridge between mechanisms of response to environmental conditions and the ecological and evolutionary significance of those responses. Accordingly, this discipline has direct ties to how different ecological factors impose limits on the energy budgets of organisms. Both internal (e.g. digestive capacity) and external (e.g. ambient temperature, atmospheric pressure, water availability, social interactions) conditions can affect the flow of materials (Wiegert 1968) through impacts on the acquisition, absorption, allocation and expenditure of energy (Karasov 1986; Weiner 1992). In this context, understanding how animals work requires an understanding of their energy budget which, for autotrophic organisms, represents the integration of energy intake, storage and loss. Thus, a major goal of ecological physiology is to understand the factors that determine energy budgets (McNab 2002). In general, such factors can be divided into limits on the rate of resource acquisition (e.g. foraging rate, rates of digestion and absorption) and limits on energy expenditure (e.g. mechanical work, heat production, water loss, tissue growth; Weiner 1992). Energy acquisition and expenditure, however, do not function in the same way; while processes for energy intake occur in sequence, processes for energy expenditure are parallel and can be additive (Weiner 1992; Bacigalupe $\&$ Bozinovic 2002). As a result, we have divided the following review of energy budgets into consideration of factors affecting energy intake versus those affecting energy expenditure (Fig. 1).

\section{Energy intake}

We focus our review of energy intake on the digestive system, which is where energy is extracted from food and enters the physiological machinery of the focal organism. Clearly, digestive physiology is important and can influence key life history features such as growth, reproduction, and survival (Karasov 1986). Multiple studies have shown that the digestive system responds to changes in biotic as well as abiotic elements of the environment (Karasov \& Douglas 2013), leading to the expectation that digestive physiology is under strong selective pressure. Below, we consider several ways in which mammals may alter their digestive physiology to respond to changes in environmental conditions.
Dietary variation. One way that mammals may alter their digestive physiology and energy intake is through changes in food consumption. For example, when fed a low quality diet, captive Talas tucotucos (Ctenomys talarum) consumed more food and devoted more time to feeding than when provided with a high quality diet (Perissinotti et al. 2009). No morphological differences in the gastrointestinal tracts of these animals were observed (del Valle \& López Mañanes 2008, 2011), suggesting that response to variable diet quality relies in large part on behavioral adjustments. This may include changes in the frequency of coprophagy (i.e. reingestion of fecal items), which is common in rodents, including $C$. talarum (Martino et al. 2007, Perissinotti et al. 2009). Because coprophagy in this species occurs across all diets, however, it is possible that reingestion of feces is driven more by acquisition of essential nutrients (e.g. vitamins and aminoacids) than energy intake (Martino et al. 2007; Perissinotti et al. 2009). Changes in diet composition in response to environmental conditions have also been reported for Phyllotis xanthopygus (Sassi et al. 2017). Members of this species captured at different elevations in the Andes varied between omnivorous and granivorousfrugivorous diets in relation to habitat conditions. Changes in digestive physiology and energy intake were also reported across the elevations sampled (Sassi \& Novillo 2015). Although additional studies of these types are needed, we propose that changes in food resources and food consumption are common responses to variable environmental conditions that have important implications for energy intake.

Digestive efficiency. Digestive efficiency provides a critical link between extrinsic factors (e.g. food resources) and intrinsic processes such as extraction of energy from food resources. One of the primary determinants of digestive efficiency is the quality of food consumed (Karasov 1986; Bozinovic 1993). Within species, diet quality can affect both the morphology and physiology of the gastrointestinal tract. For example, gut length in the omnivorous sigmodontine rodent Akodon azarae increased when captive individuals were maintained on a low quality diet (del Valle et al. 2006); this change occurred in the anterior portion of the gut, where digestion and energy absorption typically take place. A low quality diet was also associated with digestive changes at the cellular level (Sabat et al. 1999); A. azarae fed a low quality diet displayed reduced sucrose-specific hydrolytic activity in the small intestine, indicating a down-regulation of the sucrase-isomaltase enzyme complex involved in digestion of carbohydrates (del 


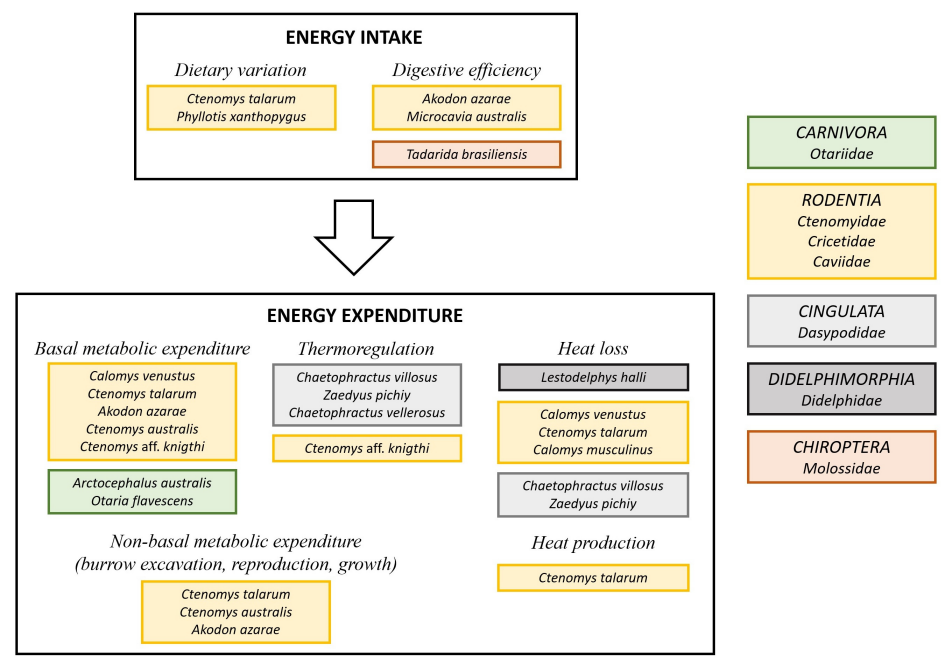

Fig. 1. Summary of species from Argentina that have been used to address different fundamental themes regarding the energetics of mammals. The topics indicated are explored in this review; the species shown are those that have been studied with regard to these topics. The taxonomic list at right summarizes the higher level (order, family) diversity represented by these studies.

Valle et al., 2006). Similar changes in digestive physiology were evident in A. azarae exposed to low ambient temperatures (del Valle et al. 2004), suggesting that changes in carbohydrate processing and thus digestive efficiency in these animals may be a general response to challenging environments. Dietinduced changes in digestive efficiency have also been reported for the herbivorous cavy Microcavia australis; Sassi et al. (2007) reported that among free-living populations of this species, differences in diet quality were associated with size variation in digestive organs, particularly the caecum. In captivity, differences in digestibility and retention time were observed in relation to differences in diet quality (Sassi et al. 2010), providing further evidence that digestive efficiency varies in response to the resources consumed.

Across species, fundamental differences in mammalian life history traits may also impact digestive efficiency. For example, the digestive system of bats is generally similar to that of non-volant mammals, with the exception of the large intestine, which is relatively short in chiropterans compared to other mammals (Caviedes-Vidal et al. 2007). This morphological difference may reflect a trade-off between a reduction in internal organ size that facilitates flight and an associated reduction in gut absorptive capacity (Price et al. 2015). As an apparent form of compensation for the reduced surface area available in the large intestine, bats absorb watersoluble nutrients (glucose, aminoacids) through a passive-transport system that occurs via paracellular junctions (Price et al. 2015). For example, studies of populations of the insectivorous bat Tadarida brasiliensis from Argentina revealed high levels of paracellular absorption (Fasulo et al., 2013, CaviedesVidal et al. 2008), a finding that was linked to an increased number of tight junctions in the intestine (Price et al. 2013). Indeed, T. brasiliensis has more villous area and a greater number of enterocytes per area than non-volant mammals (Zhang et al. 2015), which facilitate their reliance on paracellular absorption (Price et al. 2013). Thus, over evolutionary time scales, the challenges imposed by different mammalian life history patterns may also result in changes in the mechanisms underlying digestive efficiency.

\section{Energy expenditure}

Energy that is acquired by an organism can be spent in multiple ways. This includes expenditures required simply to maintain the most basic life processes such as respiration, as well as expenditures associated with more specialized activities such as thermogenesis, reproduction, or escape from predators. Below, we briefly review forms of energy expenditure that are common to mammals, with emphasis on how these expenditures may change in response to extrinsic environmental conditions. 


\section{Basal metabolic expenditures}

In endotherms, one of the primary physiological variables used to assess minimum energy expenditure is basal metabolic rate (BMR). Estimates of BMR are generated under standardized conditions (e.g. thermoneutral, non-reproductive, inactive phase of circadian cycle) so as to provide a measure of the minimum energy necessary to maintain homeostasis (Hulbert \& Else 2004). Studies of BMRs for Argentine mammals are largely restricted to rodents. One of the first such studies was conducted on A. azarae (Dalby \& Heath 1976); this classic analysis estimated BMRs for captive individuals. Subsequently, Antinuchi and Busch (2000) estimated BMR for a larger number of members of this species that had been obtained directly from the field, resulting in values of BMR similar to those reported by Dalby \& Heath (1976). In contrast to these surface-dwelling rodents, members of the genus Ctenomys are subterranean and, accordingly, display morpho-physiological features thought to reflect adaptations to life in underground burrows (Nevo 1999). Busch (1989) examined the metabolism of two species of ctenomyids, revealing that in both Ctenomys talarum and C. australis, BMR was lower than that for surface-dwelling rodents of similar body size.

Following these pioneering efforts, studies of Argentine mammals have increasingly focused on the ecological and evolutionary contexts underlying diversity in physiological processes. Because environments are dynamic, variability in morphophysiological responses (i.e. phenotypic plasticity; Spicer \& Gaston, 1999) should improve an individual's ability to cope with temporal changes in environmental conditions and multiple studies have now examined variability in the physiological responses of individuals. For example, Perissinotti et al. (2009) evaluated the effects of experimentally induced differences in diet quality and soil hardness on BMR in C. talarum while Luna et al. (2012) examined the effects of acclimation to different ambient temperatures on the same physiological parameter; while diet quality and soil hardness were associated with differences in BMR, ambient temperature had no apparent effect on this variable. Over somewhat longer time periods, seasonal variation in BMR was not detected for C. talarum (Meroi et al., 2014) although Tachinardi et al. (2017) reported that for C. aff. knighti, winter BMRs were lower if surface activity was restricted to the daytime, which is when above-ground activity by these animals is typically observed (Tomotani et al. 2012). Thus, variation in environmental conditions appears to elicit changes in individual metabolic physiology over multiple time scales.

In some species, particular life history traits (e.g. specialization for marine habitats) makes it difficult to quantify BMR; in these taxa, resting metabolic rate (RMR) is typically reported (Speakman et al. 2004; Withers et al., 2016). For example, Dassis et al. (2012) quantified RMR in Southern sea lions (Otaria flavescens) while the animals were at rest on the ground, at rest floating in water, and swimming underwater. Estimates of RMR increased across these three conditions, as expected based on anticipated energetic costs of terrestrial versus marine conditions and resting versus active individuals. RMR has also been used to assess energetic expenditure by juvenile South American fur seals (Arctocephalus australis; Dassis et al. 2014). While BMR and RMR clearly differ in terms of the specific metabolic information provided, both measures have been used to assess the relative energetic costs of differences in activity and environmental conditions.

All of the above studies were based on analyses of intraspecific variation in BMR or RMR. Analyses of interspecific differences in metabolic rates are needed to identify large-scale patterns of energetic expenditure. Primary determinants of variation in BMR include body mass and phylogenetic background (Kleiber 1932; Hayssen \& Lacy 1985; Mueller \& Diamond 2001). Considerable variation in BMR, however, remains after correction for body mass and phylogeny (McNab 1988, 2009), suggesting that other factors also contribute to differences in BMR. These additional factors include ambient temperature (Naya et al. 2013), diet type (i.e. herbivores versus carnivores; McNab 1986), climatic factors (i.e. Ta and precipitation; Rezende et al. 2004), latitude (Lovegrove 2003) and zoogeographical zones (Lovegrove 2000). To the best of our knowledge, the only studies of Argentine mammals to have examined interspecific variation in BMR have focused on the rodent genus Ctenomys rodents. Contrary to data from surface-dwelling rodents, BMRs in Ctenomys are not affected by differences in climate, soil conditions, habitat productivity or net primary productivity (Luna et al. 2009). This outcome is consistent with the long-standing expectation that subterranean environments tend to be relatively stable (Buffenstein 2000), leading to the prediction that among ctenomyids, environmental differences may affect energetic variables other than BMR (e.g. maximum metabolism: Luna et al. 2009, 2017). Clearly, further research is needed to understand 
how body size, phylogenetic history, and environmental conditions interact to shape the energetics of these and other Argentine mammals.

\section{Thermoregulation}

In mammals and other endotherms, body temperature $(\mathrm{Tb})$ reflects the balance between metabolic heat production and loss of that heat to the environment. Both of these parameters may vary over the course of the 24 -hr cycle, leading to circadian variation in $\mathrm{Tb}$. For example, Casanave \& Affanni (1994) reported that in the hairy armadillo Chaetophractus villosus, $\mathrm{Tb}$ was lower in the morning than during the afternoon $\left(35.1^{\circ} \mathrm{C}\right.$ and $36.1^{\circ} \mathrm{C}$, respectively). Factors thought to play key roles in regulating circadian patterns of $T \mathrm{~b}$ include the light-dark cycle as well as daily fluctuations in ambient temperature and food availability (Refinetti 2010). For example, even among individual Ctenomys aff. knighti housed in complete darkness, Tachinardi et al. (2014) found daily fluctuations in $\mathrm{Tb}$ that were synchronized with the 24-hr light-dark cycle. With regard to ambient temperature, Seitz and Puig (2018) reported that daily variation in external temperatures had a strong effect on $\mathrm{Tb}$ in the hairy armadillo Zaedyus pichiy, although a comparable effect was not detected for two other species of hairy armadillos (Chaetophractus vellerosus, and Ch. villosus).

\section{Heat production}

In terms of metabolic heat production, total thermogenic capacity and the underlying components (i.e. shivering and non-shivering thermogenesis) have been quantified for only a single Argentine mammal, C. talarum. In this species, non-shivering thermogenesis (NST) did not vary with acclimation to low Tas and did not appear to be the primary source of heat production (Luna et al. 2012). Similarly, maximum metabolic rate (MMR) did not differ with acclimation to cold or warm environments (Luna et al. 2012), suggesting that thermogenic capacity is already maximal in warm acclimation. Given that these subterranean rodents live in what are expected to be relatively stable thermal environments, the implications of these data for other, surface dwelling species are not clear. Comparative data from a greater range of taxa and from species occupying a greater diversity of habitats are required to evaluate fully the role of NST versus other forms of heat production in Argentine mammals.

\section{Heat loss}

Mammals use multiple mechanisms to reduce loss of metabolic heat, including huddling and changes in body fat or pelage. More specialized forms of reducing heat loss include torpor, which has been reported for some species of Argentine mammals. More specifically, Caviedes-Vidal et al. (1990) found that the mouse Calomys venustus became torpid when exposed to low Tas, a response that may facilitate survival in environments with wide thermal fluctuations (Caviedes-Vidal et al. 1990). Torpor has also been reported for the Patagonian opossum (Lestodelphys halli), in which $T \mathrm{~b}$ varied with cold exposure and periods of torpor persisted for up to $\sim 10 \mathrm{~h}$ (Geiser \& Martin 2013). In other species, torpor appears to be triggered by variation in diet quality (i.e., energetic intake rather than heat loss). For example, when experimentally subjected to a low quality diet, armadillos (Z. pichyi) spent $\sim 6 \mathrm{~h}$ at sub-normal $T \mathrm{~b}$, while animals fed a standard diet allowed $T \mathrm{~b}$ to drop for no more than $1 \mathrm{~h}$ (Superina \& Jahn 2013). Z. pichyi is the only species of xenarthran that is known to hibernate, with hibernation bouts (interrupted by short periods of euthermia) lasting $\sim 75 \mathrm{~h}$ (Superina \& Boily 2007). Thus, in addition to morphological adaptations, at least some Argentine mammals use modifications of metabolic rate to conserve heat.

Conversely, dissipation of metabolic heat may be a challenge for some species, particularly terrestrial taxa that are exposed to high ambient temperatures. Heat may be lost to the environment via direct physical routes (conduction, convection, radiation) or via evaporative water loss. Direct loss of heat is likely to be facilitated by properties of the pelage. For example, Jofré \& Caviedes-Vidal (2003) reported seasonal variation in heat transfer via fur in Calomys musculinus, with loss of heat being greater during the summer. Although Cutrera \& Antinuchi (2004) did not measure heat transfer directly, they reported seasonal changes in the density and length of fur in the subterranean rodent $C$. talarum, with both measures decreasing during summer. Heat dissipation may also be affected by changes in behavior that alter the surface area available for thermal conductance. Luna \& Antenucci (2007a) found that, while digging, C. talarum did not display changes in $T \mathrm{~b}$ in response to changes in ambient temperature; these authors proposed that the animals press their ventral surface against the substrate while digging, thereby increasing conductive heat loss. Increased contact with the substrate has also been proposed for the 
armadillo Chaetophractus villosus, which displayed decreased $T \mathrm{~b}$ when experimentally covered with soil (Casanave \& Affanni 1995).

Evaporative water loss may be particularly effective at high ambient temperatures because this mechanism does not rely on a thermal gradient (Withers et al. 2016) between an organism and its environment. Evaporative water loss (EWL; Stitt 1976) is a standardized physiological measurement used to estimate the loss of heat due to evaporation; mechanisms such as sweating, salivation or panting that increase EWL are expected to also increase evaporative heat loss. Among Argentine mammals, EWL in C. talarum remained constant below and within the animals' thermoneutral zone but increased above thermoneutrality (Baldo et al. 2015). This outcome was not influenced by relative humidity (Baldo et al. 2016); because the air in underground burrows is typically very moist, it may impede evaporation, suggesting that other forms of heat loss such as conductance may be more important in subterranean species such as $C$. talarum (see Luna \& Antenucci 2007b). More generally, because evaporative heat loss also results in loss of water, the relative importance of this cooling mechanism is expected to vary between arid and more mesic habitats.

\section{Water balance and osmoregulation}

Water is an essential component of the mammalian body and its abundance must be regulated to maintain homeostasis. In mammals, water is obtained both exogenously (e.g. direct intake or through food) and endogenously (e.g. production of metabolic water during catabolism). Loss of water occurs via excretion of urine and feces as well as through evaporation. Much of the research on water balance in mammals has focused on mechanisms for reducing water loss, such as producing urine that is significantly more concentrated than plasma (SchmidtNielsen 1997). The ability of mammalian kidneys to produce concentrated urine depends on the length of the loops of Henle and collecting ducts that traverse the renal medulla, with the lengths of both structures being directly related to the thickness of the renal medulla (see McNab 2002). Accordingly, medullary thickness has been used as an index of renal capacity to concentrate urine. Diaz \& Ojeda (1999) compared renal structure across multiple species of Argentine rodents as a function of environmental water availability. These authors found that among rodents that occupy desert habitats, murid species (Salinomys delicatus, Andalgalomys olrogi, A. roigi, C. musculinus, Eligmodontia moreni, E. typus) had the greatest relative medullary thickness and most concentrated urine. Within octodontids, the salt flat specialist Tympanoctomys barrerae had a higher renal index and greater urine osmolarity than the closely related but somewhat more generalist Octomys mimax and Octodontomys gliroides (Diaz \& Ojeda 1999, Diaz \& Cortés 2003). Comparisons of several species of Akodon from habitats with different rainfall regimes revealed that the capacity to concentrate urine was higher in the more ariddwelling A. iniscatus and A. azarae than in the more mesic-living A. cursor (Antinuchi and Busch 1999). Baldo et al. (2019) observed that $C$. talarum is able to concentrate urine beyond the level required under conditions of low water availability. Diaz et al. (2001) found that food deprived Thylamys pusilla displayed the highest reported value of osmolarity for an insectivorous marsupial. Thus, studies of multiple mammal lineages provide morphological and physiological evidence that kidney function varies predictably with environmental aridity, presumably as a means of reducing water loss in drier habitats.

Other potential adaptations to reduce water loss include increased uptake of water vapor via aquaporins in nasal turbinates (Gallardo et al. 2008; Castellar et al. 2015) and the absorption of water in the intestine (Gallardo et al. 2002; Bozinovic \& Gallardo 2006). To date, no studies have been performed in Argentine mammals to evaluate the importance of either route in the conservation of body water. Finally, mammals may use a wide range of behavioral strategies (e.g. burrow construction, nocturnal activity) to reduce the probability of experiencing water imbalance (Bozinovic \& Gallardo 2006); these potential adaptations also require additional study in Argentine mammals. More generally, future studies should explore the interplay between morphological, physiological and behavioral mechanisms for reducing water loss across a variety of environmental settings.

\section{Non-basal energetics}

Most animals spend the majority of their lives operating under non-basal metabolic conditions. As a result, measurement of energetic expenditure under a wide range of non-basal conditions is critical to understanding the actual energy budgets of most free-living mammals. To the best of our knowledge, only one species of Argentine mammal -C. talarumhas been studied with regard to how energetic costs change across different basic life history activities. As analyses of this species reveal, energetic demands can change markedly with activity, suggesting that 
studies of basal metabolic demands are not sufficient to understand the energy physiology of free-living animals.

\section{Burrow excavation}

C. talarum is subterranean, meaning that individuals spend the majority of their time in underground burrows that they excavate for themselves (Lacey et al. 2000). Digging new tunnels is thought to be very energetically costly (see Vleck 1979) and, in general, subterranean species are characterized by low BMRs compared to those for surface-dwelling rodents of similar body mass. The "cost-of-burrowing hypothesis" posits that reduced BMR may help to compensate for the metabolic demands imposed by digging to create new burrows or to modify existing tunnel systems (Vleck 1979, 1981). In contrast, the "thermal-stress hypothesis" argues that low BMR minimizes the risk of overheating in confined and poorly ventilated burrow environments in which convective and evaporative heat loss are restricted (McNab 1966, 1979). To evaluate these hypotheses, Luna \& Antenucci $(2006,2007 \mathrm{~b})$ analyzed the effect of soil hardness on digging metabolic rates (DMR) in two species of ctenomyids. These authors reported that in both $C$. talarum and C. australis, DMR for animals living in soft soils increased as soil hardness increased; in contrast, metabolic rates for animals living in hard soils did not change. Further, in $C$. talarum, increasing the incline at which animals were digging to $>40^{\circ}$ also resulted in an increase in DMR (Luna \& Antenucci 2007c), suggesting that both soil conditions and burrow architecture affect the metabolic costs of burrow excavation. Energetic demands imposed by these factors may, in turn, interact with other extrinsic factors; Luna \& Antenucci (2007a) demonstrated that metabolic rates while digging increased for C. talarum at low ambient temperatures and that the energy generated during digging was used in part to supply the energy required for thermoregulation. In contrast, at high temperatures, the increase of DMR did not affect $T b$, presumably because the animals made greater use of conductive heat loss when digging. Overall, these findings fail to provide clear support for either the cost-ofburrowing or thermal-stress hypotheses and, indeed, both ideas may contribute to the understanding of the metabolic costs of digging.

\section{Reproduction}

For female mammals, reproduction is one of the most energetically costly activities that an individual can undertake (Tomasi \& Horton 1992), with reproduction accounting for as much as $50 \%$ of a female's annual energy budget (Kenagy 1987). During pregnancy, the energetic requirements of females increase due to the need to support fetal growth as well as the growth of maternal reproductive structures (Thompson 1992). Lactation is typically the most expensive portion of the reproductive cycle, with energy expenditures rising to greater than 23 times those associated with gestation (Künkele 2000a;b). These estimates do not take into account the energetic costs of securing mates or providing other forms of maternal care, all of which may further enhance the costs of reproduction.

Considerable research has focused on the apparent evolutionary trade-off between the duration of gestation versus lactation and the relative energetic requirements of each of these portions of the reproductive cycle, a dynamic that is expected to vary with general differences in life-history strategies (Thompson 1992). In C. talarum, females experience increased energetic demands during gestation and lactation, although the cost of these two stages of reproductive appear to be similar (Zenuto et al. 2002). The lack of a pronounced increase in energetic needs during lactation is thought to reflect the general reproductive biology of this species; like other hystricognath rodents, ctenomyids undergo a long period of gestation that results in the production of relatively precocial neonates (Weir 1974). The only other study to have examined the reproductive energetics of Argentine rodents revealed that in Akodon azarae, metabolic rates for pregnant and lactating females are higher than those for nonbreeding females (Antinuchi and Busch 2001), although the relative costs of gestation and lactation were not assessed for this species.

\section{Growth}

As indicated above, newborn ctenomyids tend to be more precocial than neonates in some other lineages of rodents (e.g. murids; Weir 1974). Although newborn $C$. talarum are largely furless and initially highly dependent on parental care, they quickly become mobile and begin eating solid food very early during their postnatal development. With regard to energetic demands, Zenuto et al. (2002a) reported that prior to postnatal day 10 , the metabolic rates of pups increase although these individuals are not yet capable of maintaining a stable $T \mathrm{~b}$. Once young begin to eat solid food, their metabolic rates decrease; individuals achieve adult $T$ b's by $35-45$ days after birth and display adult metabolic rates by $\sim 90$ days after birth (Zenuto et al. 2002; Cutrera et 
al. 2003). While neonates are clearly dependent on their mothers to maintain body temperature, short daily isolation of pups does not affect the acquisition of adult $T \mathrm{~b}$ and metabolic rate (Baldo et al. 2014). Neonatal A. azarae are altricial and in this species, development of homeothermy is positively associated with litter size (Antinuchi and Luna 2002).

As should be evident, understanding energy budgets allows us to better compare the responses of organisms to the environments in which they live and, ultimately, to assess the evolution of physiological variation among species (McNab 2002). To facilitate such understanding, one of the primary goals of future research should be to examine physiological variation at different hierarchical levels from individuals to species assemblages- so as to identify the sources and determinants of the diversity in physiological systems. Studies of the energetics of Argentine mammals provide a logical starting point for more comprehensive analyses of the physiology of individual species as well as more comparative analyses of physiological variation across larger taxonomic scales. Given the compelling evidence for rapid climatic changes at a global scale (IPCC 2013), these types of studies should become increasingly important to understanding current organismal responses and, thus, predicting responses to future environmental change (Bradshaw \& Holzapfel 2010; Somero 2010; Huey et al. 2012).

\section{ECOLOGICAL ENDOCRINOLOGY}

Hormones regulate numerous diverse activities including growth, development, reproduction, metabolic rate, water balance, blood homeostasis and adaptation to stress, and thus measuring hormone concentrations provides an important method for quantifying a wide spectrum of responses to environmental conditions (Wingfield 2018). Further, the quantification of hormones can serve as a proxy to evaluate many aspects of physical condition, survival, and reproductive success of individuals, for which it would otherwise be necessary to record ecological information (e.g. sex, age, reproductive condition) over extended time periods (Cooke et al 2013; Dantzer et al. 2014). In free-living mammals, obtaining such information is not easy due to the longevity of most species and the difficulties of trapping, marking and observing individuals in nature and thus hormonal estimates of physiology are particularly valuable to studies of these organisms.

\section{Glucocorticoid hormones}

In mammals, as in other vertebrates, stressful stimuli (e.g. drought, limited food, predator threats, social upheaval) trigger the activation of the hypothalamicpituitary-adrenal (HPA) axis and, consequently, the production of glucocorticoid (GC) hormones, notably cortisol and/or corticosterone. In the short term, GC-mediated physiological and behavioral responses help animals to cope with environmental stressors, although prolonged exposure to stressors may negatively impact an individual's condition, such that survival and reproduction are compromised (Sapolsky et al. 2000; Boonstra 2005). More specifically, depending on the severity of the challenges experienced and their effects on energetic needs and availability, individuals will face different degrees of allostasis, including potential allostatic overload (McEwen \& Wingfield 2003). Given that GCs play a primary role in energy mobilization and mediate multiple regulatory functions -including response to stressors- recording changes in cortisol and/or costicosterone in relation to different ecological conditions and environmental challenges can provide critical information regarding the physiological condition of the animals under study (Vera et al. 2018; MacDougall-Shackleton et al. 2019).

Estimates of GC levels can be obtained from multiple sources. One of the most commonly assayed sources of GCs is blood plasma, especially to capture acute stress responses. While blood plasma provides a critical measure of circulating GC levels, using plasma requires that blood samples be obtained quickly (e.g. immediately after capture) to avoid including the acute pulse of GCs released as a consequence of capture and handling. Plasma levels of GCs have been assessed for two Argentine species of subterranean rodents: Ctenomys talarum (Vera et al. 2011a, 2012, 2013, 2018) and C. sociabilis (Woodruff et al. 2010). In addition, plasma measures of GCs have been obtained for guanacos (Lama guanicoe; Carmanchahi et al. 2011; Taraborelli et al. 2011, 2017) and vicuñas (Vicugna vicugna; Arzamendia \& Vilá 2012; Marcoppido et al. 2017). In general, however, analyses of circulating GC levels remain scarce for mammals from Argentina and adjacent parts of South America.

Alternatively, levels of GC metabolites can be measured from urine, feces, saliva, hair, feathers, respiratory vapor, and baleen. Fecal samples in particular offer several advantages, namely avoidance of acute responses to capture, handling, restraint, anesthesia, and sample collection. Given that fecal 
samples capture information about GC production over a period of multiple hours, care must be taken to account for potential confounding factors such as differences in metabolism, sex, diet, reproductive status, and portion of the circadian cycle, each of which may influence the hormone concentrations of individuals (Goymann 2012; Romero \& Reed 2005). Among Argentine mammals, measures of fecal GC metabolites have been completed for colonial tucotucos (C. sociabilis; Woodruff et al. 2010, 2013), domestic chinchillas (Chinchilla lanigera; Ponzio et al. 2004; Mastromonaco et al. 2015), pichis (Zaedyus pichiy; Superina et al. 2009), howler monkeys (Alouatta caraya; Cantarelli et al. 2017), and guanacos L. guanicoe (Ovejero Aguilar et al. 2016) Other materials that have been assayed include urine (C. lanigera: Ponzio et al. 2004; Mastromonaco et al. 2015) and baleen (Eubalaena australis; Fernández Ajó et al. 2018).

The relative abundance of cortisol and corticosterone may vary with the specific taxon under study. Among mammals, cortisol generally tends to be the most abundant GC; although corticosterone tends to dominate in Rodentia, this pattern varies among rodent species (see Woodruff et al. 2010; Vera et al. 2012, 2018). For example, while corticosterone was identified as the primary GC in plasma and fecal samples from female C. sociabilis (Woodruff et al. 2010), both GCs are found in plasma in C. talarum (Vera et al. 2011a). In the latter species, cortisol is responsive to acute and chronic stressors as well as to challenge with adrenocorticotropic hormone (ACTH) while corticosterone is not (Vera et al. 2011a, 2012, 2013, 2018). Further, inhibition by dexamethasone occurs for both GCs in free-living animals but only for cortisol in captive individuals (Vera et al. 2018) Finally, plasma levels for both GCs -in particular corticosterone- fluctuate seasonally and between years, resulting in a significant temporal variation in the ratio of circulating cortisol to corticosterone (Vera et al., 2011a, 2012, 2013).

\section{Factors affecting GC levels}

Intrinsic and extrinsic factors, in conjunction with anthropogenic disturbances, can affect baseline GC levels as well as physiological responses to different stressors. Differences in GC levels may arise due to intrinsic attributes of individuals, including parameters such as sex, reproductive condition, ontogenetic history, and recent stressful experiences (Dantzer et al. 2014). Studies of free-living and captive mammals from Argentine have explored the effects of different intrinsic factors (Fig. 2). In at least two species (C. talarum; Vera et al. 2012; A. caraya; Cantarelli et al. 2017), cortisol levels were typically higher for females than for males, presumably due to the greater energetic demands on females associated with reproduction and or social interactions. Female guanacos also displayed higher levels of cortisol than males; potential explanations for this finding include sex-based differences in baseline GC levels as well as differential response to stressors (Carmanchahi et al. 2011). Among vicuñas, GC response to capture methods has been shown to vary between the sexes (Arzamendia et al. 2010). Changes in GC levels are expected to vary in relation to reproduction. Higher cortisol levels in male guanacos during the reproductive season were related to energetic demands of reproductive and associated social interactions (Ovejero Aguilar 2016). Both males and females of $C$. talarum showed higher cortisol levels during the reproductive season compared to other portions of the year (Vera et al. 2013). With regard to developmental experience, predatory prenatal stress did not influence the stress response to immobilization in juvenile $C$. talarum (Brachetta et al. 2018). Collectively, these findings suggest that information regarding basic phenotypic parameters is required to understand patterns of GC variation and physiological stress response in freeliving populations of mammals.

GC levels may also be influenced by a variety of ecological and anthropogenic factors, operating independently or in conjunction with each other. Studies of free-living and captive mammals from Argentina have explored the effects of multiple such factors, including the following (Fig. 2):

a. Diet. Because GCs are involved in the regulation of energy balance, it is logical to predict that diet is an important determinant of GC levels in mammals (Reeder et al. 2004). Data from captive C. talarum appear to support this expectation; individuals fed with a low quality diet displayed increased cortisol levels (Vera et al. 2018). Diet likely impacts other physiologically important parameters such as glucose, triglycerides, and inflammatory response (Merlo et al. 2016a), suggesting that no single biomarker of physiological condition is sufficient for capturing the effects of this factor and thus future studies will benefit from recording multiple elements of response, as has been done for $C$. $t a-$ larum (Vera et al. 2008, 2011a, 2013, 2018, Brachetta et al. 2018), guanacos (Carmanchahi et al. 2011; Taraborelli et al. 2017) and vicuñas (Arzamendia \& Vilá 2012; Marcoppido et al. 2017). 
b. Social relationships. The social environment in which an individual lives may affect the stressors that it experiences. In particular, while solitary animals may be more subject to stressors associated with food shortages or predator exposure, those living in groups face additional stressors arising due to regular social interactions with conspecifics. In this context, Woodruff et al. (2013) compared baseline GC levels in lone versus group living yearling female $C$. sociabilis, finding that in both captive and free-living populations, lone females had higher baseline GC levels. These authors suggest that while lone females must respond to all environmental challenges on their own, females in groups share some of these challenges, thus reducing the impact on each individual in a group, thereby underscoring the role that social environment may play in mediating response to challenge.

c. Predator threats. Predators affect prey directly through mortality as well as indirectly through impacts on behavior, foraging opportunities, and reproductive success; these more indirect effects may, in turn, be reflected in the stress physiology of individuals (Clinchy et al. 2013). To explore these impacts, analyses of GC levels in the baleen of southern right whales (E. australis: Fernández Ajó et al. 2018) have been completed for a population located near Península Valdez that has been subject to high calf mortality in recent years (Sironi et al. 2015). Loss of calves is thought to be related to attacks by Kelp Gulls (Larus dominicanus), which cause significant injuries while feeding on the skin and blubber of young animals (Marón et al 2015). Sampling of baleen from stranded whales has revealed elevated levels of both cortisol and corticosterone, with a clear relationship between GC levels and the severity of wounds resulting from gull predation (Fernández Ajó et al. 2018, Dickens \& Romero 2013). Thus, even sub-lethal predation may affect GC responses in free-living mammals. While changes in GC levels are associated with the mobilization of energy required for antipredatory behavioral responses, relationships between physiological and behavioral variables may be complex in vertebrates. Studies of captive C. talarum have revealed that cortisol secretion increases when these animals are exposed to predator odor and immobilization (simulating capture by a predator). However, the moderate magnitude of the resulting endocrine response is consistent with predation pressure that is alleviated by the use of subterranean burrows by this species. This physiological response was accompanied by changes in performance in an elevated plus maze, providing evidence that predator exposure impacts both GC production and behavioral response (Brachetta et al. 2019).

d. Anthropogenic activities. As indicated above, GC levels may be influenced by a variety of conditions, including whether individuals are free-living or housed in captivity. For example, wild female $C$. sociabilis displayed higher baseline corticosterone levels than captive conspecifics (Woodruff et al. 2010 ), potentially reflecting the greater challenges (e.g. securing food, avoiding predators) associated with natural environments (McEwen \& Wingfield 2003). Consistent with this, once in captivity, cortisol and corticosterone levels decrease markedly in C. talarum, with this change being particularly pronounced for females. Clearly, captive housing affects GC physiology in both of these species, although further studies are needed to understand whether the observed decrease in GC levels in captive animals is part of a chronic stress response to captivity (Dickens \& Romero 2013). Human activity, including the direct manipulation of wild species as well as the modification of natural environments, may have important effects on stress physiology (Madliger et al. 2016). For example, physical restraint of guanacos during shearing has been shown to be associated with increases in cortisol levels as well as increases in heart rate and body temperature (Carmanchahi et al. 2011, Taraborelli et al. 2011). Similarly, vicuñas captured for shearing displayed elevated levels of cortisol (Bonacic \& Macdonald 2003). In contrast, analyses of fecal GC metabolites for black and gold howler monkeys (A. caraya) revealed no differences in cortisol levels between animals living in human-fragmented versus continuous forest habitats (Cantarelli et al. 2017). Overall, these types of studies are critical to the conservation of threatened species such as guanacos, vicuñas, and howler monkeys and their associated habitats. At the same time, these findings underscore the complexity and context dependency of interactions among human activity, environmental conditions, and stress physiology.

\section{Reproductive hormones}

In numerous populations of free-living mammals, hormone secretion varies temporally, often in accord with reproductive seasonality. In this context, changes in energetic demands are associated with reproductive activity, and as a consequence, both GCs and reproductive hormones are fundamental 


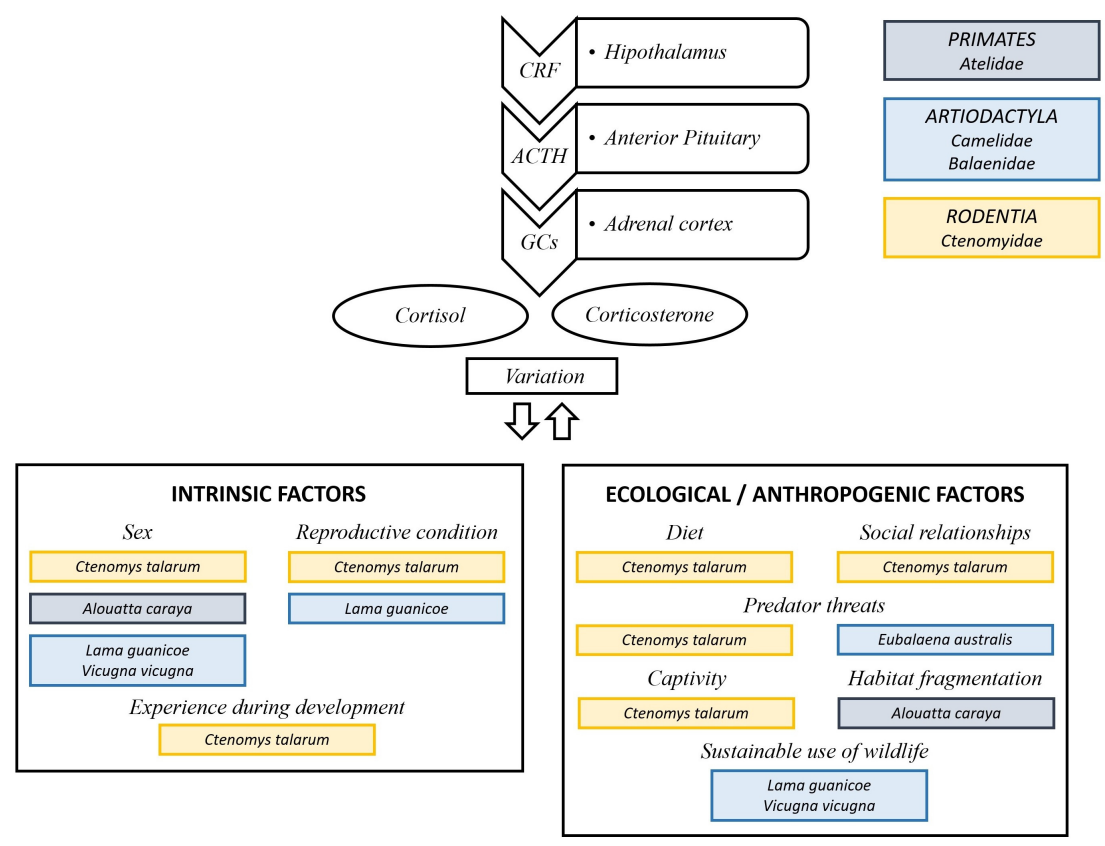

Fig. 2. Summary of research on the ecological endocrinology of mammals from Argentina, with emphasis on glucocorticoid responses to different stressors. The upper portion of the figure depicts the major components of the hypothalamic-pituitary-adrenal (HPA) axis, which regulates the production of glucocorticoid hormones. Hormones produced by this axis include corticotropin-releasing factor (CRF), adrenocorticotropic hormone (ACTH), and the glucocorticoids (GCs) cortisol and corticosterone. The lower portion of the figure lists the topics explored in this review; the species shown are those that have been studied with respect to these topics. The taxonomic list at the upper right summarizes the higher level (order, family) diversity represented by these studies.

components of the endocrine response (Place \& Kenagy; Boonstra 2005; Reeder \& Kramer 2005). Changes in reproductive hormone levels as a function of reproductive status have been reported based on analyses of urine from $A$. caraya (Raño et al 2018), plasma and urine from C. talarum (Vera et al. 2011b, 2013; Fanjul \& Zenuto 2012, 2017), plasma and feces from the armadillos Chaetophractus villosus and Ch. vellerosus (Luaces et al. 2011), urine and feces from chinchillas (Busso et al. 2005, 2007; Mastromonaco et al. 2015), and feces from pichis $Z$. pichiy (Superina \& Jahn 2009; Superina et al. 2009) and guanacos (Ovejero Aguilar 2016). In male $C$. talarum, testosterone peaked during the reproductive season although levels were highly variable among individuals, ranging from barely detectable to extremely high compared to other mammals (Vera et al. 2011b, 2013). In contrast, progesterone levels in this species did not differ between the reproductive and non- reproductive seasons (Vera et al. 2013). In captivity, female reproductive behavior varied with progesterone and oestradiol levels, with both hormone levels and vaginal cytology affected by the presence of a male (Fanjul \& Zenuto 2012). Although females displayed clear preferences for dominant males as mates, dominance was inversely related to cortisol levels and showed no relationship with testosterone levels (Fanjul \& Zenuto 2017). Hormone levels may also vary as a function of lifetime reproductive trajectory. For example, longitudinal analyses of urine samples from an elderly and a young female black and gold howler monkey revealed that the younger, reproductively active female had higher average values of progesterone metabolites and estrone conjugates, thereby providing the first evidence of potential reproductive senescence in free-living A. caraya (Raño et al. 2018).

Because successful reproduction is essential to the persistence of threatened species, understanding how environmental conditions affect production of reproductive and glucocorticoid hormones may improve our ability to protect such species. To this end, studies such as those by Busso et al. $(2005,2007)$, who used urine to examine gonadal endocrine activity in chinchillas, may provide valuable information for conservation breeding programs for this and other 
species that are endangered in the wild. Similarly, gonadal endocrine activity has been assessed in male and female pichis (Ch. villosus), which are also of conservation concern in Argentina (Superina $\&$ Jahn 2009; Superina et al. 2009). Because the morphology of these animals makes it difficult to monitor reproductive status based on external cues or (for females) vaginal smears, use of endocrine data to track hormonal (progesterone) changes in feces is an important tool for monitoring the reproductive physiology of armadillos (Luaces et al. 2011) and, potentially, other species of mammals.

Given that hormones regulate such diverse aspects of organismal function as development, reproduction, metabolic rate, water balance, and response to stressors, our understanding of different endocrine processes represents a powerful method for evaluating how individuals respond to changing environmental conditions. Despite the importance of such information, relatively little work has been completed on the eco-endocrinology of Argentina mammals. Indeed, the first studies on this topic -analyses of armadillos and chinchillas- were completed only fourteen years ago. Although studies of guanacos, vicuñas, tuco-tucos, howler monkeys and whales have followed, the number and diversity of mammalian taxa for which endocrine data are available remains limited. Conceptually, the primary topic that has been explored is response to stressors associated with diet, predation, social interactions, and anthropogenic activity (direct manipulation of animals as well as changes to their habitats). While a few of these studies have also assessed impacts on other physiological parameters such as reproduction, much remains to be learned about interactions among these systems and their implications for management of both threatened and pest species. We assert that ecological endocrinology represents an important but underutilized tool for monitoring free-living animals in nature as well as implementing better, more controlled laboratory experiments. The information reviewed here should serve as a foundation for future studies of the ecoendocrinology of mammals from Argentina.

\section{ECOLOGICAL IMMUNOLOGY}

All living organisms are exposed to a wide range of pathogens and thus have evolved complex physiological responses to resist or to tolerate these threats (Råberg et al. 2008); collectively, these different lines of defense against invading pathogens constitute the immune system (Demas \& Nelson 2012). Although pathogens are expected to exert strong selective pressures on their hosts by affecting variables intimately linked to fitness, hosts exhibit great variability in the strength and efficiency of their immune strategies. The field of ecological immunology, or "ecoimmunology", aims to understand this variability by examining the interactions between host physiology (i.e. immune function) and disease ecology (i.e. pathogen prevalence) in a wide range of environments and animal species. This field of study first emerged at the beginning of the 21 st century, with early studies focusing primarily on birds (i.e. Martin et al. 2003, 2006a; Eraud et al. 2005); among mammals, emphasis to date has been on surface-dwelling rodents (i.e. Derting \& Compton 2003; Martin et al. 2006b). Within Argentina, research in this discipline began approximately 10 years ago with studies that explored energetic aspects of immunity as well as trade-offs between immunity and other costly processes in a number of local vertebrate species, with emphasis on field and laboratory studies of non-model mammalian species such as tuco-tucos (Ctenomys talarum; Cutrera et al. 2010, 2011; Merlo et al. 2014a, 2016b, 2018) and capybaras (Hydrochoerus hydrochaeris; Eberhardt et al. 2013, 2015).

Variation in disease susceptibility may be driven by extrinsic factors such as temporal and geographic changes in pathogen prevalence but can also be the result of intrinsic changes in host immunity, as well as interactions among these elements. This variability in the magnitude and efficiency of host immune responsiveness may have a genetic basis (Kubinak \& Potts 2012) and/or may be attributed to the balance between the obvious benefits of mounting an immune response and the costs of doing so, a trade-off that also mediates interactions between immunity and other costly activities such as reproduction (Demas et al. 2012, Fig. 3). In this context, the role of Major Histocompatibility Complex (MHC) genes in immune recognition as well as the forces driving the extremely high levels of polymorphism that characterize these loci (i.e. pathogen selection, Doherty \& Zinkernagel 1975) have been studied in three Argentine species of subterranean rodent, the Patagonian tuco-tuco C. haigi, the colonial tuco-tuco C. sociabilis (Hambuch \& Lacey 2002), and the talas tuco-tuco (C. talarum; Cutrera \& Lacey 2006, Cutrera et al. 2011, 2012, 2014). Here, however, we focus on studies that have assessed the costs of immunity and the trade-offs involving immune function that are mediated by these costs, as well as the critical insights that these analyses have generated into 
immune system function in natural populations of mammals.

\section{Costs of immunity}

Immunity, just like other physiological processes, requires energy to be activated and to be maintained over time. Accordingly, immune defense is expected to confer both fitness benefits in the form of resistance against pathogen infections and substantial costs, which can be energetic and/or nutritional, among others (Lochmiller \& Deerenberg 2000, Hasselquist \& Nilsson 2012). As a result, variability in immune strategies is expected to arise from the trade-offs between allocating resources to immunity versus other costly processes (Sheldon \& Verhulst 1996). Although this dynamic makes it essential to estimate the direct metabolic costs of the different components of the immune system, few studies have explored this topic in mammals of Argentina (Cutrera et al. 2010; Merlo et al. 2014a). One exception are analyses of $C$. talarum, in which the energetic consequences of triggering an immune response were assessed using a novel nonpathogenic antigen (sheep red blood cells, SRBC) to activate the adaptive immune response (Cutrera et al. 2010). These authors reported a significant increase in oxygen consumption among immunechallenged (injected with SRBC) compared to control animals; this increase in oxygen consumption corresponds to a $15 \%$ increase in the daily energetic expenditure (DEE) of a tuco-tuco, which is a substantial change that may have significant impacts on body condition in wild individuals. Among the components of immunity, inflammation, which is triggered primarily by the entry of microorganisms or tissue damage, is considered to be associated with a large energetic expenditure arising from the production of lymphocytes required for this type of cell-mediated adaptive response (Klasing \& Leshchinsky 1999). To test this assumption, Merlo et al. (2014a) used a subcutaneous injection of phytohemagglutinin (PHA) to induce an inflammatory response in C. talarum. PHA is a plant lectin that is widely used in ecological studies because it permits assessment of the costs of inflammation without triggering additional costs associated with pathogen replication and tissue damage to the host (Martin et al. 2006c). Results from tuco-tucos (Merlo et al. 2014b) indicate that, contrary to what has been demonstrated for birds (Martin et al. 2006), PHA triggers both innate and adaptive immune responses (presence of lymphocytes, neutrophils, eosinophils, and macrophages at the site of injection). This local inflammatory response, however, is not associated with increased oxygen consumption, indicating that an immune challenge may not always result in a detectable energetic cost. (Merlo et al. 2014a).

Studies that manipulate resource availability have tended to confirm that triggering and maintaining the immune system is energetically costly. However, interpretation of these results is challenging due to the effect that food restriction has on general condition; the reported effects of food manipulation on immunity may instead reflect more general impacts on individual condition (the so-called "vicious circle", see Beldomenico \& Begon 2010). To explore this dynamic, Merlo et al. (2016a) assessed the effect of diet manipulations on nutritional state, the magnitude of the inflammatory response to PHA, and other multiple immune parameters (e.g. bacterial killing capacity, natural antibodies, and leukocyte profile) in C. talarum. Individuals under food restriction displayed an altered nutritional status as well as increased stress levels (higher neutrophil:lymphocyte ratios) and a marked reduction in the inflammatory response to PHA compared to individuals fed ad libitum. Supplementation with methionine, however, did not affect any of the parameters analyzed and endoparasite loads were not affected by any treatments. These findings support the assertion that food insufficiency can modulate immune responsiveness through lack of adequate essential nutrients, through metabolic fuel and energetic reserves, or through detrimental effects of the stress caused by nutrient limitation.

Although initial studies of response to PHA (Merlo et al. 2014a) reported no substantial associated energetic cost in C. talarum, the response to PHA did involve pronounced nutritional demands; this is in contrast to what has been found regarding the nutritional requirements of the adaptive antibody response to SRBC in this species. Antibody response against SRBC (Cutrera et al. 2010) did not vary in magnitude between animals subjected to slight versus severe food restriction (Schleich et al. 2015), suggesting that energetically demanding processes are not always more compromised during periods of nutrient deficiency than are processes with lower energetic costs. Nonetheless, nutrient limitation may be one of the most important environmental factors affecting immunocompetence and hence disease resistance. For example, Agostini et al. (2017) used an experimental approach to evaluate the reciprocal effects of nutritional status and parasitism in two groups of black capuchin monkeys (Sapajus nigritus) from Iguazú National 


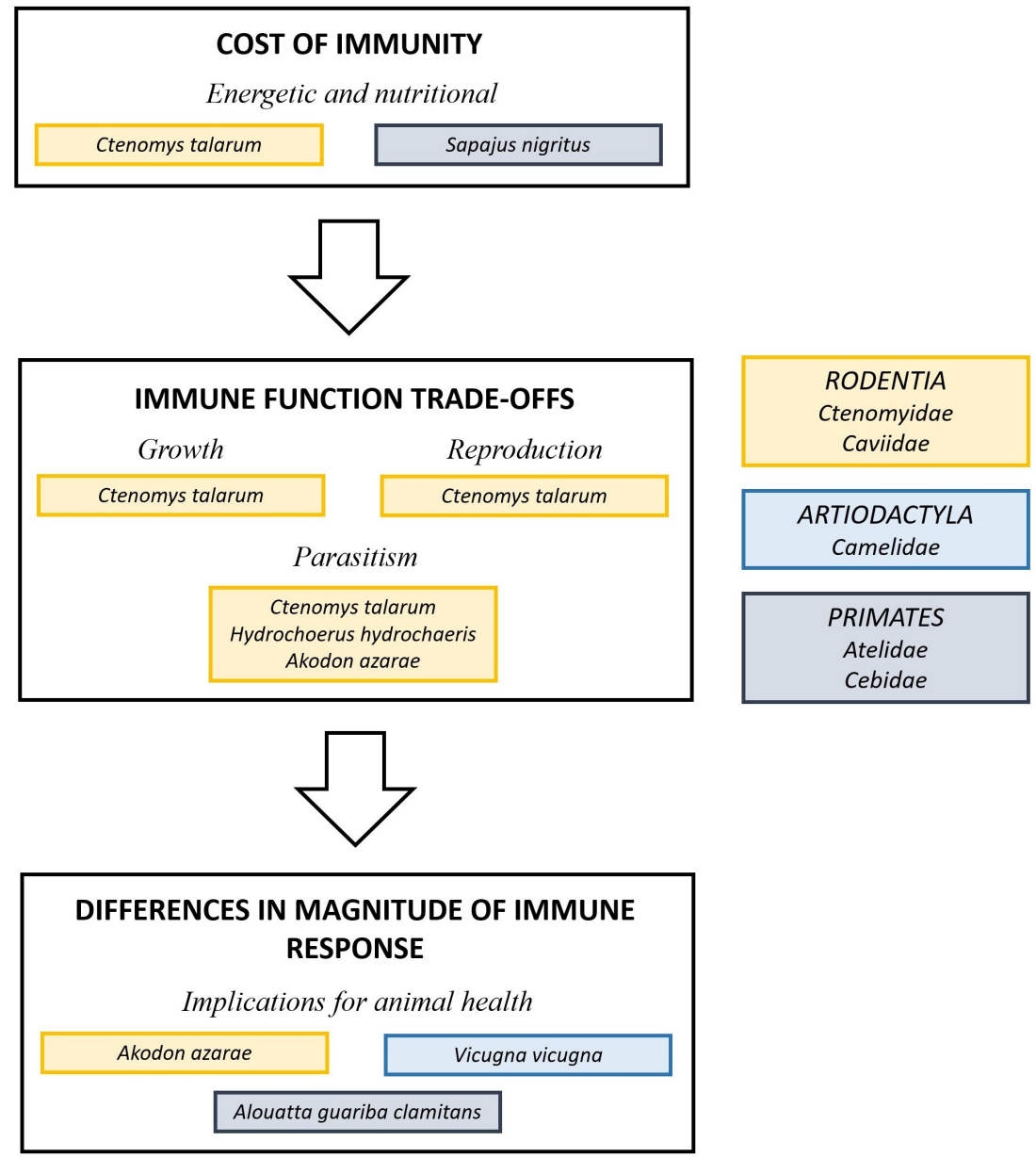

Fig. 3. Summary of research on ecological immunology in mammals from Argentina. The primary topics covered by this review are indicated, as are the species used to address each of these topics. The taxonomic list to the right provides the higher level (order, family) diversity represented by these studies.

Park in Misiones, Argentina. Food availability was manipulated by provisioning monkeys with bananas, and parasite burdens were modified by applying antiparasitic drugs to selected individuals. Although no effect of antiparasitic drugs on physical condition was detected, parasite loads decreased in response to high levels of food availability, lending support to the prediction of the "vicious circle" hypothesis (Beldomenico \& Begon 2010) that nutritional status should impact parasite dynamics, and hence, physical condition.

\section{Immune function trade-offs}

Growth. The energetic costs of mounting and maintaining an immune response can also be assessed indirectly by determining whether exposure to immune challenge triggers the re-allocation of energy away from other costly physiological processes such as growth and reproduction (Derting \& Compton 2003). In turn, the magnitude and efficiency of an immune response may be negatively affected by these other processes. For example, in sexually dimorphic species, members of the larger sex may invest less in immune response, presumably because they have to allocate more energy towards growth (Fargallo et al. 2002; Chin et al. 2005). In addition to a negative relationship between these physiological demands (Fair et al. 1999), immune response of young animals is expected to be lower than that of adults due to immaturity of the immune system. However, 
when juvenile C. talarum were challenged with PHA, they mounted a greater inflammatory response than adults with no differences in magnitude between the sexes despite the marked sexual dimorphism in body size among adult of this species (Cutrera et al. 2014). Clearly, the energetics of immune response are more complex than originally envisioned and understanding the energetic consequences of such responses requires further investigation of multiple aspects of an organism's physiology during different developmental stages and periods of varying energetic demands.

Reproduction. Life-history theory predicts that individuals will adjust their investment in current reproduction to the level at which the sum of current and future fitness is maximized (Stearns 1992). As a consequence, particularly energetically costly reproductive stages may depress immunocompetence. In $C$. talarum, the increase in oxygen consumption triggered by challenging animals with SRBC was lower for females during the breeding season compared to the non-breeding season. Interestingly, antibody titers for females did not decrease during the breeding season (Cutrera et al. 2010), suggesting that future work should examine the potential role of pregnancy in facilitating the production of Th-2 cells and humoral immunity in this species (Cutrera et al. 2010). When PHA-induced inflammatory response was assessed, however, no differences in energetic investment or in the magnitude of the swelling response were found between the breeding and nonbreeding seasons or between the sexes. Thus, in C. talarum, the inflammatory response appears to be less costly than the adaptive immune response with the result that the former may not be subject to significant trade-offs with other energy-demanding processes such as reproduction (Merlo et al. 2014a).

Parasitic infections. Existing parasitic infections may enhance or suppress immune response to a new challenge (Page et al. 2006). The negative effect of parasitism on immune response may reflect either competition for host resources by different pathogens or a general impoverishment of host condition (Cox 2001). Alternatively, immune processes triggered by simultaneous challenges could interact directly via induced immunodepression by parasites or synergistic or antagonistic effects on different immune pathways (Cox 2001). Interactions among different pathogens remain difficult to understand, which is probably why few parasitological or ecological studies have focused on more than one pathogen. Recently, however, Colombo et al. (2015a, b) found numerous interactions among loads of immature stages of the tick Amblyomma triste and other ectoparasites of Akodon azarae, suggesting that co-infections may be important for tick dynamics. Merlo et al. (2016b) examined the influence of multiple challenges on immune responsiveness in C. talarum by comparing the impacts of the natural parasite community plus those of experimental infection with a coccidian (Eimeria sp.) on PHAinduced inflammation and a variety of immune, condition, nutrition, and stress parameters. In this species, the inflammatory response triggered by PHA was impaired by infection with Eimeria, either alone or in conjunction with infection by a number of gastrointestinal nematodes. However, with the exceptions of erythrocyte sedimentation rate and the magnitude of local swelling (both proxies of inflammation), no other physiological parameters were affected by parasitism. This is in contrast to data from capybara, in which parasitism by Trypanosoma evansi was associated with detrimental effects on host body condition as well as altered biochemical and hematological parameters (Eberhardt et al. 2017). Collectively, these findings suggest that parasitism is a key factor modulating immune responsiveness in at least some species of mammals from Argentina.

\section{Effects of life history}

In a seminal publication on ecological immunology, Lee (2006) proposed that the relative effort spent on either the innate or the adaptive portions of the immune system may be influenced by a species' life history. Specifically, Lee (2006) predicted that the relative magnitude of the activation of each of these portions of the immune response should be related to the pace of life of an organism. Further, a species' relative metabolic rate may impose limits on the synthetic processes involved in the adaptive immune response (Brown et al. 2004; Auer et al. 2018). Therefore, "slow-living" species with long lifespans and high investment in offspring are expected to exhibit stronger adaptive immunity, particularly with regard to antibody production, which is slower but confers immunological "memory" against repeated infections, which are more likely to occur in longlived species. Merlo et al. (2019) explored this prediction using studies of $C$. talarum which, among rodents, is a slow-living species (Antinuchi et al. 2007; Busch et al. 1989; Zenuto et al. 2001, 2002a,b) that is exposed to a high prevalence of infections by a relatively limited suite of parasites (Rossin \& Malizia 2002). These traits led Merlo et al (2019) to predict that $C$. talarum should rely more strongly on the adaptive rather than the innate component 
of immunity. However, injecting animals with PHA (triggers both innate and adaptive responses in tucotucos; Merlo et al. 2014b) and SRBC (allows estimation of adaptive immune response), revealed that the magnitudes and energetic costs of each portion of the immune response were similar; this outcome was the same for animals treated with one or both challenges, suggesting the absence of an energetic or resource-based trade-off between the responses triggered by PHA and SRBC (Merlo et al. 2019).

Implications for animal health. Beldomenico and Begon (2016) defined the health of a wild animal as the "state of balance between the stressors (including parasites) and the physiological regulatory network of the host (including the stress response and the immune function)". In this context, assessing generic indices of the health of wild animals in their natural habitats not only increases our knowledge of their natural history, but also provides information required to evaluate interactions between extrinsic (i.e. seasonal) and intrinsic (i.e. genetic, neural, endocrine) factors affecting immune response. Among ecoimmunologists, there has been a growing tendency to use multiple functional assays to estimate the combined strength of the different portions of the immune system (Adamo 2012). Other measures such as behavioral patterns or proxies of physiological condition may help to estimate disease resistance. One of the first studies of a mammal of Argentina to measure multiple biochemical and physiological parameters (blood cell counts, serum protein fractions, and spleen mass) and to relate these parameters to differences in sex, body condition, pregnancy status, and season was conducted in free-living capybara (Eberhardt et al. 2015). In captivity, food restricted capybara displayed poorer body condition, higher eosinophil counts, and lower helminth counts than control animals (Eberhardt et al. 2013). In contrast, among free-living animals, body condition was negatively associated with eosinophil counts. These comparisons underscore the importance of physiological data from wild populations as a reference for experimental manipulations conducted under more controlled conditions (i.e. captive settings).

Multivariate analyses of the factors associated with prevalence of immature stages of the tick $A$. triste on one of its main hosts in Argentina, the rodent $A$. azarae (Colombo et al. 2015a), revealed significant associations among larval tick burdens and several environmental factors, including the presence of cattle. This outcome underscores the importance of considering the ecoepidemiological implications of human agricultural practices on dynamics of parasites such as of A. triste, which is the vector for the human pathogen Rickettsia parkeri in the southern cone of South America. More recently, Merlo et al. (2018) explored the influence of condition of individual $C$. talarum on the magnitude of the inflammatory response induced by PHA. Their results provide further evidence that parasitism, reproductive condition and leukocyte counts affect response to this challenge, which is one of the most frequently-used tests to assess immunocompetence in wild species of mammals.

In sum, ecoimmunological studies conducted to date on Argentine mammals have generated multiple new insights into the factors that shape variation in immune responsiveness in wild species in their natural habitats. Further, these studies have contributed to improved conservation strategies for species subject to disease threats, such as brown howler monkeys (Alouatta guariba clamitans) and susceptibility to yellow fever (Agostini et al. 2014; Moreno et al. 2015). Application of ecoimmunological principles has also contributed to greater knowledge of hostparasite dynamics involving species of public health concern, such as relationships between A. triste, which carries Rikettsia, and its primary host, the rodent A. azarae (Colombo et al. 2015b). Finally, these studies have provided important information regarding the role of wild species as vectors of diseases that affect domestic animals (Marcoppido et al. 2010).

\section{FUTURE DIRECTIONS}

Conducting a review on the development and degree of advancement of a given scientific discipline is informative for many reasons. By assessing the extent of current understanding of a topic, questions and lines of inquiry in need of further development can be identified. Further, these efforts help to acknowledge the value of specific disciplines, such as the role of ecological physiology in understanding individual responses to changing environmental conditions and associated impacts on population status, management and conservation. As a result, reviews such as this one allow us to carry out more robust research and contribute to increased knowledge of methods and tools needed to preserve biodiversity. In sum, periodically reviewing biological disciplines should facilitate the expansion of scientific knowledge, the conservation of our fauna, and the efficient management of natural systems.

To date, studies of the ecological physiology of Argentine mammals have focused on only a limited number of species. Not surprisingly, taxonomic 
representation is particularly narrow for newer conceptual themes such as ecological immunology. Even more established topics such as energetics, however, have been explored primarily in rodents, most likely reflecting the challenges associated with monitoring many lineages of mammals in their natural habitats or establishing those species in the laboratory. Future studies will benefit from including a wider diversity of mammalian taxa as study subjects. This enhanced diversity will allow greater comparison across species, thereby facilitating our understanding of the roles of life history, habitat, and phylogeny in ecological physiology.

Field and laboratory studies are complementary and, together, allow a more comprehensive understanding of the factors affecting the ecological physiology of animals. While not all mammal species are amenable to captive housing, more can be done to integrate data from free-living populations with information obtained under more controlled conditions. Such efforts are important because they generate valuable information on performance in both types of settings; contrasts between data sets are often particularly informative regarding the factors affecting physiological and other aspects of organismal function.

In all environments, use of multiple biomarkers is essential to characterizing the physiological profile of an organism. This includes assessment of body condition, health, and stress parameters, all of which may influence the specific physiological responses discussed here. Studies of Argentine mammals have begun to use multiple indicators of condition, recognizing that their interdependence reflects their role as regulatory components of a single, unified physiological system. We urge that this effort be expanded so as to improve our understanding of the diverse factors that drive observed variation in energy use, immune responsiveness, and ability to cope with stressful situations among members of free-living mammals in their natural habitats

\section{ACKNOWLEDGMENTS}

We wish to dedicate this contribution to Dra. Cristina Busch, who founded the Ecophysiology Laboratory at the University of Mar del Plata. We thank to all members of the Lab. We are very grateful to the editors for inviting us to participate in this special issue of Mastozoología Noetropical and especially to Eileen A. Lacey for her helpful comments on an earlier version of the manuscript.

\section{LITERATURE CITED}

ADAMO, S. 2012. The importance of physiology for ecoimmunology: Lessons from the insects. Ecological Immunology (G. E. Demas \& R. J. Nelson, eds.). Oxford University Press.

Agostini et AL. 2017. Experimental testing of reciprocal effects of nutrition and parasitism in wild black capuchin monkeys. Scientific Reports 7: 12778

Agostini, I. ET AL. 2014. Building a species conservation strategy for the brown howler monkey (Alouatta guariba clamitans) in Argentina in the context of yellow fever outbreaks. Tropical Conservation Science 7:25-34.

ANTinUChi, C. D., ש C. Busch. 1999. Intrageneric comparisons in urine-concentrating capacity and renal morphology among three species of Akodon from different geographic rainfall regimens. Zeitschrift für Säugetierkunde 64:277-284.

Antinuchi, C. D., \& C. Busch. 2000. Metabolic rates and thermoregulatory characteristics of Akodon azarae (Rodentia: Sigmodontinae). Revista Chilena de Historia Natural 73: 131-138

Antinuchi, C. D., \& C. Busch. 2001. Reproductive energetics and thermoregulatory status of nestlings in Pampas mice Akodon azarae (Rodentia: Sigmodontinae). Physiological \& Biochemical Zoology 74:319-324.

Antinuchi, C. D., \& F. Luna. 2002. Assessing the effect of litter size on growth pattern and homeothermy acquisition in the Pampas mice Akodon azarae (Rodentia, Muridae). Growth, Development and Aging 66:63-69.

Antinuchi, C. D., R. R. Zenuto, F. Luna, A. P. Cutrera, P. P. Perissinotti, \& C. Busch. 2007. Energy budget in subterranean rodents: insights from the tuco-tuco Ctenomys talarum (Rodentia: Ctenomyidae). The Quintessential Naturalist: Honoring the Life and Legacy of Oliver P. Pearson (D.A. Kelt, E. Lessa, J. A. Salazar-Bravo, \&J. L. Patton, eds.). University of California Publications in Zoology.

ArZamendia, Y., Æ B. VilÁ. 2012. Effects of capture, shearing and release on the ecology and behaviour of wild vicunas. Management \& Conservation 76: 57-64.

Arzamendia, Y., C., Bonacic, \& B. Vilá. 2010. Behavioural and physiololgical consequences of capture for shearing of vicuñas in Argentina. Applied Animal Behaviour Science 125:163-170.

Auer S., C. Dick, \& N. Metcalfe. 2018. Metabolic rate evolves rapidly and in parallel with the pace of life history. Nature Communications 9:1-6.

Bacigalupe, L. D., \& F. Bozinovic. 2002. Design, limitations and sustained metabolic rate: lessons from small mammals. The Journal of Experimental Biology 205:2963-2970.

BALDo, M. B., \& C. D. AnTenUCCI. 2019. Diet effect on osmoregulation in the subterranean rodent Ctenomys talarum. Comparative Biochemistry \& Physiology A 235:148-158.

Baldo, M. B., C. D. Antenucci, \& F. Luna. 2015. Effect of ambient temperature on evaporative water loss in the subterranean rodent Ctenomys talarum. Journal of Thermal Biology 53:113118.

Baldo, M. B., C. D. Antenucci, \& F. Luna. 2016. Does acclimation to contrasting atmospheric humidities affect evaporative water loss in the South American subterranean rodent Ctenomys talarum $<\mathrm{U}+202 \mathrm{~F}>$ ? Journal of Mammalogy 97:1312-1320.

Baldo, M. B., F. Luna, C. E. Schleich, \& C. D. Antenucci. 2014. Thermoregulatory development and behavior of Ctenomys talarum pups during brief repeated postnatal isolation. Comparative Biochemistry \& Physiology A 173:35-41.

Beldomenico, P. M., ש M. Begon. 2010. Disease spread, susceptibility and infection intensity: vicious circles? Trends in Ecology \& Evolution 25:21-27.

Beldomenico, P. M., \& M. Begon. 2016. Stress-host-parasite interactions: A vicious triangle? Revista FAVE Sección Ciencias Veterinarias 14: 6-19. 
BonAcic, C., \& D. W. MAc DonAld. 2003. The physiological impact of wool harvesting procedures in vicuñas (Vicugna vicugna) Animal Welfare 12:387-402.

Boonstra, R. 2005. Equipped for life: the adaptive role of the stress axis in male mammals. Journal of Mammalogy 86:236-247.

Bozinovic F. (ED.). 2003. Fisiología Ecológica y Evolutiva: Teoría y casos de estudios en animales. Pp. 531. Universidad Católica de Chile, Santiago, Chile.

Bozinovic, F. 1993. Fisiología ecológica de la alimentación y digestión en vertebrados: Modelos y teorías. Revista Chilena de Historia Natural 66:375-382.

Bozinovic, F., \& P. A. Gallardo. 2006. The water economy of South American desert rodents: From integrative to molecular physiological ecology. Comparative Biochemistry \& Physiology C 142:163-172.

Bozinovic, F., P. Calosi \& P. A. Gallardo. 2011. Physiological correlates of geographic range in animals. Annual Review of Ecology, Evolution, and Systematics 42:155-179.

Brachetta, V., C. E. Schleich, A. P. Cutrera, C. E. Merlo, M. J Kittlein, \& R. R. Zenuto. 2018. Prenatal predatory stress in a wild species of subterranean rodent: do ecological stressors always have a negative effect on the offspring? Developmental Psychobiology 60:567- 581.

Brachetta, V., C. E. Schleich, \& R. R. Zenuto. 2019. Differential antipredatory responses in the tuco-tuco (Ctenomys talarum) in relation to endogenous and exogenous changes in GCs. Journal of Comparative Physiology A. DOI: 10.1007/s00359-019-01384-8.

Bradshaw, W. E. \& C. M. Holzapfel. 2010. Light, time, and the physiology of biotic response to rapid climate change in animals. Annual Review of Physiology 72:147-166.

Brown, J. H., J. F. Gillooly, A. P. Allen, V. M. Savage, \& G. B. WEST. 2004. Toward a metabolic theory of ecology. Ecology 85:1771-1789.

BufFENSTEIN, R. 2000. Ecophysiological responses of subterranean rodents to underground habitats. Life Underground: The Biology of Subterranean Rodents (E. A. Lacey, G. Cameron, \& J. L. Patton, eds.). The University of Chicago Press, Chicago, Illinois, USA Pp 62-110.

Busch, C. 1989. Metabolic rate and thermoregulation in two species of tuco-tuco, Ctenomys talarum and Ctenomys australis (Caviomorpha, Octodontidae). Comparative Biochemistry \& Physiology A:345-347.

Busch, C., A. I. Malizia, O. A. Scaglia, ひ O. A. Reig. 1989. Spatial distribution and attributes of a population of Ctenomys talarum (Rodentia: Octodontidae). Journal of Mammalalogy 70:204-208.

Busso, J. M., M. F. Ponzio, M. Fiol De Cuneo, \& R. D. Ruiz. 2007. Noninvasive monitoring of ovarian endocrine activity in the chinchilla (Chinchilla lanígera). General \& Comparative Endocrinology 150:288-297.

Busso, J. M., M. F. Ponzio, M. Fiol De Cuneo, ひ R. D. Ruiz. 2012 Reproduction in chinchilla (Chinchilla lanigera): current status of environmental control of gonadal activity and advances in reproductive techniques. Theriogenology 78:1-11.

Busso, J. M., M. F. Ponzio, V. Dabbene, M. Fiol De Cuneo, \& R. D Ruiz. 2005. Assessment of urine and fecal testosterone metabolite excretion in Chinchilla lanigera males. Animal Reproduction Science 86: 339-351.

Cantarelli, V. I., M. A. Perez-rueda, M. M. Kowalewski, G. F Mastromonaco, \& M. F. Ponzio. 2017. Validation of an enzyme immunoassay and comparison of fecal cortisol metabolite levels in black and gold howler monkeys (Alouatta caraya) inhabiting fragmented and continuous areas of the humid Chaco region, Argentina. American Journal of Primatology 79: e22625.

Carmanchahi, P. D. ET AL. 2011. Physiological response of wild guanacos to capture for live shearing. Wildlife Research 38: 6168.

Casanave, E. B., \& J. M. Affanni. 1994. Body temperature of the armadillo Chaetophractus villosus (Mammalia, Dasypodidae).
Archives Internationales de Physiologie, de Biochimie et de Biophysique 102:243-246.

Casanave, E. B., \& J. M. Affanni. 1995. Decrease of body temperature in Armadillos experimentally covered by soil. Archives of Physiology and Biochemistry 103:29-32.

Castellar, A., P. C. Bertoli, L. H. Galdino, R. F. Domeniconi, o A. P. Cruz-neto. 2015. Differences in physiological traits associated with water balance among rodents, and their relationship to tolerance of habitat fragmentation: Tolerance of rodents to habitat fragmentation. Journal of Experimental Zoology A 323:731-744

Caviedes-Vidal, E., E. C. Codelia, V. Roig, \& R. Dona. 1990. Facultative torpor in the south american rodent Calomys venustus (Rodentia: Cricetidae). Journal of Mammalogy 71:72-75.

Caviedes-Vidal, E., T. J. Mc Whorter, S. R. Lavin, J. G. Chediack, C. R. Tracy, $\mho$ W. H. Karasov. 2007. The digestive adaptation of flying vertebrates: High intestinal paracellular absorption compensates for smaller guts. Proceedings of the National Academy of Sciences 104:19132-19137.

Caviedes-Vidal, E., W. H. Karasov, J. G. Chediack, V. Fasulo, A. P. CRUZ-NETO \& L. OTANi. 2008. Paracellular absorption: a bat breaks the mammal paradigm. PLoS ONE 3:e1425.

Chin, E., O. Love, \& A. CLARK. 2005. Brood size and environmental conditions sex-specifically affect nestling immune response in the European starling Sturnus vulgaris. Journal of Avian Biology 36:549-554.

Clinchy, M., M. J. Sheriff, \& L. Y. Zanette. 2013. Predatorinduced stress and the ecology of fear. Functional Ecology 27:5665.

Colombo, V. C. Eт AL. 2015a. Factors affecting patterns of Amblyomma triste (Acari: Ixodidae) parasitism in a rodent host. Veterinary parasitology 211:251-258.

Colombo, V. C. ET AL. 2015b. Ecology of the interaction between Ixodes loricatus (Acari: Ixodidae) and Akodon azarae (Rodentia Criceridae). Parasitology research 114:3683-3691.

Cooke, S. J. ET AL. 2013. What is conservation physiology? Perspectives on an increasingly integrated and essential science. Conservation Physiology 1: doi:10.1093/conphys/cot001.

Cox, F. E. G. 2001. Concomitant infections, parasites and immune responses. Parasitology 122:23-38.

Cutrera, A. P., \& C. D. Antinuchi. 2004. Cambios en el pelaje del roedor subterráneo Ctenomys talarum: posible mecanismo térmico compensatorio. Revista Chilena de Historia Natural 77:235-242.

Cutrera, A. P., C. D. Antinuchi, \& C. Busch. 2003. Thermoregulatory development in pups of the subterranean rodent Ctenomys talarum. Physiology \& Behavior 79:321-330.

Cutrera, A. P., R. R. Zenuto, \& E. A. Lacey. 2011. MHC variation, multiple simultaneous infections and physiological condition in the subterranean rodent Ctenomys talarum. Infection, Genetics \& Evolution 11:1023-36.

Cutrera, A. P., R. R. Zenuto, ひ E. A. Lacey. 2014. Interpopulation differences in parasite load and variable selective pressures on MHC genes in Ctenomystalarum. Journal of Mammalogy 95:679695.

Cutrera, A. P., R. R. Zenuto, F. Luna, \& C. Antenucci. 2010. Mounting a specific immune response increases energy expenditure of the subterranean rodent Ctenomys talarum (tucotuco): implications for intraspecific and interspecific variation in immunological traits. Journal of Experimental Biology 213:715724.

Cutrera, A. P., ש E. A. LAcey. 2006. Major histocompatibility complex variation in talas tuco-tucos: the influence of demography on selection. Journal of Mammalogy 87;706-716.

Cutrera, A. P., M. S. Fanjul, \& R. R. Zenuto. 2012. Females prefer good genes: MHC-based mate choice in wild and captive tuco-tucos. Animal Behaviour 83:847-856.

Dalby, P. L., \& A. G. HeATH. 1976. Oxygen consumption and body temperature of the Argentine field mouse, Akodon azarae, in 
relation to ambient temperature. Journal of Thermal Biology 1:177-179.

Dantzer, B., Q. E. Fletcher, R. Boonstra, \& M. J. Sheriff. 2014. Measures of physiological stress: a transparent or opaque window into the status, management and conservation of species? Conservation Physiology 2: doi:10.1093/conphys/cou23.

Dassis, M., D. H. Rodríguez, E. N. IEno, \& R. W. Davis. 2012 Submerged swimming and resting metabolic rates in Southern sea lions. Journal of Experimental Marine Biology \& Ecology 432-433:106-112.

Dassis, M., D. H. Rodríguez, E. N. Ieno, P. E. Denunzio, J Loureiro, \& R. W. DAvis. 2014. Resting metabolic rate and heat increment of feeding in juvenile South American fur seals (Arctocephalus australis). Comparative Biochemistry \& Physiology A 168:63-68.

Del Valle, J. C., \& A. A. López Mañanes. 2008. Digestive strategies in the South American subterranean rodent Ctenomys talarum. Comparative Biochemistry \& Physiology A 150:387-394.

Del VAlle, J. C., ひ A. A. López MañAnes. 2011. Digestive flexibility in females of the subterranean rodent Ctenomys talarum in their natural habitat. Journal of Experimental Zoology A 315:141-148.

Del Valle, J. C., A. A. López Mañanes \& C. Busch. 2004 Phenotypic flexibility of digestive morphology and physiology of the South American omnivorous rodent Akodon azarae (Rodentia: Sigmodontinae). Comparative Biochemistry \& Physiology A 139:503-512.

Del Valle, J. C., C. Busch, \& A. A. López Mañanes. 2006 Phenotypic plasticity in response to low quality diet in the South American omnivorous rodent Akodon azarae (Rodentia: Sigmodontinae). Comparative Biochemistry \& Physiology A 145:397-405.

Demas, G., \& R. Nelson (EDS.). 2012. Ecoimmunology. Oxford University Press.

Demas, G., T. Greives, E. Chester, \& S. French. 2012. The energetic of immunity: Mechanisms mediating trade-offs in ecoimmunology. Ecological Immunology (G. E. Demas \&R. J Nelson, eds.). Oxford University Press.

Derting, T., \& S. Compton. 2003. Immune response, not immune maintenance, is energetically costly in wild white-footed mice (Peromyscus leucopus). Physiological \& Biochemical Zoology 76:744-752

DíAZ, G. B., \& A. CoRTÉs. 2003. Pequeños mamíferos en ambientes desérticos: Los problemas de conservación de agua. Fisiología ecológica y evolutiva: teoría y casos de estudios en animales ( $\mathrm{F}$. Bozinovic, ed.). Universidad Católica de Chile, Santiago, Chile.

DíAz, G. B., Æ R. A. OJEDA. 1999. Kidney structure and allometry of Argentine desert rodents. Journal of Arid Environments 41:453461.

Díaz, G. B., R. A. OJedA, $\mho$ M. DAcar. 2001. Water conservation in the South American desert mouse opossum, Thylamys pusilla (Didelphimorphia, Didelphidae). Comparative Biochemistry \& Physiology A 130:323-330.

Dickens, M. J., \& L. M. Romero. 2013. A consensus endocrine profile for chronically stressed wild animals does not exist. General \& Comparative Endocrinology 191:177-189.

Doherty, C., \& R. M. ZinkernAgel. 1975. Enhanced immunological surveillance in mice heterozygous at the $\mathrm{H}-2$ complex. Nature 256:50-52.

Eberhardt, A. T. et AL. 2013. Parasitism and physiological tradeoffs in stressed capybaras. PLoSOne8: e70382.

Eberhardt, A. T., M. F. Ruiz, P. M. Beldomenico, \& A. L. Racca. 2015. Dynamics of health of wild capybaras: biochemical and physiological parameters. Mammalia80:413-423.

Eberhardt, A., P. Beldomenico, L. Monje, \& A. Racca. 2017 Biochemical and physiological parameters associated with Trypanosoma evansi prevalence in wild capybaras. Canadian Journal of Zoology 95:913-919.

Eraud, C., O. Duriez, O. Chastel, $ひ$ B. Faivre. 2005. The energetic cost of humoral immunity in the Collared Dove, Streptopelia decaocto: is the magnitude sufficient to force energy-based tradeoffs? Functional Ecology 19:110-118.

FAIR, J., \& E. HANSEN. 1999. Growth, developmental stability and immune response in juvenile Japanese quails (Coturnix coturnix japonica). Proceeding of the Royal Society, London B Biological Sciences 266:1735-1742.

FAnJul, M. S., \& R. R. ZENuto. 2012. Female reproductive behaviour, ovarian hormones and vaginal cytology of the induced ovulator, Ctenomys talarum. Acta Theriologica 57:15-27.

FANJUL, M. S., \& R. R. ZENuto. 2017. Female choice, male dominance and condition-related traits in the polygynous subterranean rodent Ctenomys talarum. Behavioural Processes 142:46-55.

Fargallo, J. A., T. LaAksonen, V. Poyri, \& E. Korpimaki. 2002. Inter-sexual differences in the immune response of Eurasian kestrel nestlings under food shortage. Ecology Letters 5:95-101.

Fasulo, V., Z. Zhang, J. G. Chediack, F. D. Cid, W. H. Karasov, \& E. CAviedes-VidAL. 2013. The capacity for paracellular absorption in the insectivorous bat Tadarida brasiliensis. Journal of Comparative Physiology B 183:289-296.

Felsenstein J. 1985. Phylogenies and the comparative method. The American Naturalist 125:1-15.

FERnÁNDEZ AJó, A. A. ET AL. 2018. Lifetime glucocorticoid profiles in baleen of Right whale calves: potential relationships to chronic stress of repeated wounding by Kelp gulls. Conservation Physiology 6, coy045; DOI 10.1093/conphys/coy045.

Gallardo, P. A., N. Olea, ש F. V. SepúlvedA. 2002. Distribution of aquaporins in the colon of Octodon degus, a South American desert rodent. American Journal of Physiology-Regulatory, Integrative and Comparative Physiology 283: R779-R788.

Gallardo, P. A., S. Herrera, K. Saffer, \& F. Bozinovic. 2008. Distribution of aquaporins in the nasal passage of Octodon degus, a South-American desert rodent and its implications for water conservation. Revista Chilena de Historia Natural 81:33-40.

Geiser, F., \& G. M. Martin. 2013. Torpor in the Patagonian opossum (Lestodelphys halli): implications for the evolution of daily torpor and hibernation. Naturwissenschaften 100:975-981.

GoymanN, W. 2012. On the use of non-invasive hormone research in uncontrolled, natural environments: the problem with sex, diet, metabolic rate and the individual. Methods in Ecology \& Evolution 3:757-765.

Hambuch, T. M., \& E. A. LACEy. 2002. Enhanced selection for MHC diversity in social tuco-tucos. Evolution 56(4), 841-845.

Hasselquist, D., \& J. A. Nilsson. 2012. Physiological mechanisms mediating costs of immune responses: what can we learn from studies of birds?. Animal Behaviour 83(6):1303-1312.

Hayssen, V., \& R. C. LACY. 1985. Basal metabolic rates in mammals: taxonomic differences in the allometry of BMR and body mass. Comparative Biochemistry \& Physiology A 81:741-754.

Huey, R. B., M. R. Kearney, A. Krockenberger, J. A. M. Holtum, M. Jess, \& S. E. Williams. 2012. Predicting organismal vulnerability to climate warming: Roles of behaviour, physiology and adaptation. Philosophical Transactions B 367: 1665-1679.

Hulbert, A. J., \& P. L. Else. 2004. Basal metabolic rate: history, composition, regulation, and usefulness. Physiological \& Biochemical Zoology 77:869-876.

Jofré, M. B., \& E. CAVIEdes-VidAL. 2003. Seasonal changes in heat transfer in the small mammal Calomys musculinus (Rodentia, Muridae). The role of the skin. Journal of Thermal Biology 28:141147.

Karasov, W. H. 1986. Energetics, physiology and vertebrate ecology. Trends in Ecology \& Evolution 1:101-104.

Karasov, W. H., \& A. E. Douglas. 2013. Comparative Digestive Physiology. Comprehensive Physiology (R. Terjung, ed.). John Wiley \& Sons, Inc., Hoboken, NJ, USA.

KenAgy, G. J. 1987. Energy allocation for reproduction in the Golden-mantled ground squirrel. Symposia of the Zoological Society of London 57:259-273.

KlAsing, K. C., \& T. V. Leshchinsky. 1999. Function, costs and bene $<\mathrm{U}+\mathrm{FB} 01>$ ts of the immune system during development 
and growth. Proceedings of the 22nd International Ornithology Congress Durban (N. J. Adams\& R. H. Slotow, eds.). Birdlife South Africa, Johannesburg.

Kleiber, M. 1932. Body size and metabolism. Hilgardia 6:315-353.

Kubinak, J. L., \& W. K. Potts. 2012. Tradeoffs limiting MHC heterozygosity. Ecological Immunology (G. E. Demas \& R. J Nelson, eds.). Oxford University Press.

KüNKELE J. 2000a. Effects of litter size on the energetics of reproduction in a highly precocial rodent, the Guinea pig. Journal of Mammalogy 81:691-700.

KÜNKELE J. 2000b. Energetics of gestation relative to lactation in a precocial rodent, the guinea pig (Cavia porcellus). Journal of Zoology 250:533-539.

Lacey E. A., J. L. Patton, \& G. N. Cameron. 2000. Linking immuneLife Underground: The Biology of Subterranean Rodents. University of Chicago Press.

LEE, K. A. 2006. Linking immune defenses and life history at the levels of the individual and the species. Integrative \& Comparative Biology 46:1000-1015.

Lochmiller, R. L., \& C. Deerenberg. 2000. Trade-Offs in Evolutionary Immunology: Just What Is the Cost of Immunity? Oikos 88:87-98.

Lovegrove, B. G. 2000. The zoogeography of mammalian basal metabolic rate. American Naturalist 156:201-219.

Lovegrove, B. G. 2003. The influence of climate on the basal metabolic rate of small mammals: a slow-fast metabolic continuum. Journal of Comparative Physiology B 173:87-112.

LuAces, J. P. ET AL. 2011. Seasonal changes in ovarian steroid hormone concentrations in the large hairy armadillo (Chaetophractus villosus) and the crying armadillo (Chaetophractus vellerosus). Theriogenology 75: 796-802.

LunA, F., \& C. D. Antenucci. 2006. Cost of foraging in the subterranean rodent Ctenomys talarum: Effect of soil hardness. Canadian Journal of Zoology 84:661-667.

LunA, F., \& C. D. Antenucci. 2007a. Effect of tunnel inclination on digging energetics in the tuco-tuco, Ctenomys talarum (Rodentia: Ctenomyidae). Naturwissenschaften 94:100-106.

LunA, F., \& C. D. Antenucci. 2007b. Energetics and thermoregulation during digging in the rodent tuco-tuco (Ctenomys talarum). Comparative Biochemistry \& Physiology A 146:559-564.

LunA, F., \& C. D. Antenucci. 2007c. Energy and distribution in subterranean rodents: Sympatry between two species of the genus Ctenomys. Comparative Biochemistry \& Physiology A 147:948-954.

Luna, F., C. D. Antenucci, \& F. Bozinovic. 2009. Comparative Energetics of the Subterranean Ctenomys Rodents: Breaking Patterns. Physiological \& Biochemical Zoology 82:226-235.

LunA, F., H. NAYA, \& D. E. NAYA. 2017. Understanding evolutionary variation in basal metabolic rate: An analysis in subterranean rodents. Comparative Biochemistry \& Physiology A 206:87-94.

Luna, F., P. RocA, J. Oliver, \& C. D. Antenucci. 2012. Maximal thermogenic capacity and non-shivering thermogenesis in the South American subterranean rodent Ctenomys talarum. Journa of Comparative Physiology B 182:971-983.

MacDougall-Shackleton, S. A., F. Bonier, L. M. Romero, ひ I. T. MOORE. 2019. Glucocorticoids an "Stress" are not synonymous. Integrative Organismal Biology 1(1): obz017. https:/doi.org/ 10.1093/iob/obz017.

Madliger, C. L. ET AL. 2016. Success stories and emerging themes in conservation physiology. Conservation Physiology 4: 10.1093/conphys/cov057.

Marcoppido, G., V. Parreño, \& B. Vilá. 2010. Antibodies to pathogenic livestock viruses in a wild vicuña (Vicugnavicugna) population in the Argentinean Andean Altiplano. Journal of Wildlife Diseases, 46 (2): 608-614.

Marcoppido, G., Y. Arzamentia, \& B. Vilá. 2017. Physiological and behavioral indices of short-term stress in wild vicuñas (Vicugna vicugna) in Jujuy province, Argentine. Journal of Applied Animal Welfare Science DOI 10.1080/10888705.2017.1403324
MARón, C. F. ET AL. 2015. Increased wounding of Southern right whale (Eubalaena australis) calves by Kelp gulls (Larus dominicanus) at Península Valdés, Argentina. PLoS One 10e0139291.

Martin, L. B., A. Scheuerlein, \& M. Wikelski. 2003. Immune activity elevates energy expenditure of house sparrows: a link between direct and indirect costs? Proceedings of the Royal Society: Biology Sciences 270:153-158.

Martin, L. B., D. Hasselquist, \& M. Wikelski. 2006a. Investment in immune defense is linked to pace of life in house sparrows. Oecologia 147: 565-575.

Martin, L. B., Z. M. Weil, J. R. Kuhlman, \& R. J. Nelson. 2006b. Trade-offs within the immune systems of female White-footed Mice, Peromyscus leucopus. Functional Ecology 20:630-636.

Martin, L. B., P., Han, J., Lewittes, J. R. Kuhlman, K. C., KLASING \& M. WiKELSKI. 2006. Phytohemagglutinin-induced skin swelling in birds: histological support for a classic immunoecological technique. Functional Ecology, 20:290-299.

Martin, L. B., P. Han, J. Lewittes, J. R. Kuhlman, K. C. Klasing, \& M. WIKELSKI. 2006c.Phytohemagglutinin-induced skin swelling in birds: histological support for a classic immunoecological technique. Functional Ecology20:290-299.

Martino N. S., R. R. Zenuto, \& C. Busch. 2007. Nutritional responses to different diet quality in the subterranean rodent Ctenomys talarum (tuco-tucos). Comparative Biochemistry \& Physiology A 147:974-982.

Mastromonaco, G. F., V. I. Cantarelli, M. G. Galeano, N. S. Bourguignon, C. Gilman, \& M. F. Ponzio. 2015. Noninvasive endocrine monitoring of ovarian and adrenal activity in chinchilla (Chinchilla lanigera) females during pregnancy, parturition and early post-partum period. General \& Comparative Endocrinology 213:81-89.

McEwen, B. S., \& J. C. Wingfield. 2003. The concept of allostasi in biology and biomedicine. Hormones \& Behavior 43: 2-15.

MCNAB, B. K. (ED.). 2002. The physiological ecology of vertebrates: a view from energetics.

McNAB, B. K. 1986. The influence of food habits on the energetics of eutherian mammals. Ecological Monographs 56:1-19.

McNAB, B. K. 1988. Complications inherent in scaling the basal rate of metabolism in mammals. The Quarterly Review of Biology 63:25-54.

McNAB, B. K. 2009. Ecological factors affect the level and scaling of avian BMR. Comparative Biochemistry and Physiology A152:2245.

McNAB, B. K. 1966. The metabolism of fossorial rodents: A study of convergence. Ecology 47:712-733.

McNAB, B. K. 1979. The influence of body size on the energetics and distribution of fossorial and burrowing mammals. Ecology 60:1010-1021.

Merlo, J. L., A. P. Cutrera, F. LunA, \& R. R. Zenuto. 2014a. PHA-induced inflammation is not energetically costly in the subterranean rodent Ctenomys talarum (tuco-tucos). Comparative, Biochemistry \& Physiology Part A 175:90-95.

Merlo, J. L., A. P. CutrerA, \& R. R. Zenuto. 2014b. Inflammation in response to phytohemagglutinin injection in the Talas tucotuco (Ctenomys talarum): implications for the estimation of immunocompetence in natural populations of wild rodents. Canadian Journal of Zoology 92:689-697.

Merlo, J. L., A. P. Cutrera, \& R. R. Zenuto. 2016a. Food restriction affects inflammatory response and nutritional state in tuco-tucos (Ctenomys talarum). Journal of Experimental Zoology Part A: Ecological Genetics \&Physiology32:675-687.

Merlo, J. L., A. P. Cutrera, \& R. R. Zenuto. 2016b. Parasite infection negatively affects PHA-triggered inflammation in the subterranean rodent Ctenomys talarum. Journal of Experimental Zoology Part A: Ecological Genetics \& Physiology325:132-141.

Merlo, J. L., A. P. Cutrera, M. J. Kittlein, \& R. R. Zenuto. 2018. Individual condition and inflammatory response to PHA in the subterranean rodent Ctenomys talarum (Talas tuco-tuco): A multivariate approach. Mammalian Biology 90:47-54. 
Merlo, J. L., A. P. Cutrera, \& R. R. Zenuto. 2019. Assessment of trade-offs between simultaneous immune challenges in a slow-living subterranean rodent. Physiological \& Biochemical Zoology 92:92-105.

Meroi F., F. LunA, \& C. D. Antenucci. 2014. Variación estacional de la tasa metabólica de reposo en Ctenomys talarum (Rodentia, Ctenomyidae): Ausencia de efectos ambientales. Mastozoología Neotropical 21:241-250.

Moreno, E. S. ET AL. 2015. Yellow fever impact on brown howler monkeys (Alouatta guariba clamitans) in Argentina: a metamodelling approach based on population viability analysis and epidemiological dynamics. Memórias do Instituto Oswaldo Cruz 110:865-876.

Mueller, P., \& J. Diamond. 2001. Metabolic rate and environmental productivity: well-provisioned animals evolved to run and idle fast. Proceedings of the National Academy of Sciences 98:1255012554.

Naya, D. E., L. Spangenberg, H. Naya, \& F. Bozinovic. 2013 Thermal conductance and basal metabolic rate are part of a coordinated system for heat transfer regulation. Proceedings of the Royal Society B: Biological Sciences 280:20131629-20131629.

Nevo E. (ED) 1999. Mosaic evolution of subterranean mammals: regression, progression, and global convergence. Oxford University Press, Oxford, New York.

Ovejero Aguilar, R. J. A., G. A., Jahn, M. Soto-gamboa, A. J Novaro, \& P. Carmanchahi. 2016. The ecology of stress: linking life-history traits with physiological control mechanisms in free-living guanacos. PeerJ4: e2640. DOI 10.7717/peerj.2640.

Page, K. R., A. L. Scott, \& Y. C. ManABe. 2006. The expanding realm of heterologous immunity: Friend or foe? Cellular Microbiology 8:185-196.

Perissinotti, P. P., C. D. Antenucci, R. Zenuto, \& F. Luna. 2009. Effect of diet quality and soil hardness on metabolic rate in the subterranean rodent Ctenomys talarum. Comparative Biochemistry \& Physiology A 154:298-307.

Place, N. J., \& G. J. Kenagy. 2000. Seasonal changes in plasma testosterone and glucocorticosteroids in free-living male yellowpine chipmunks and the response to capture and handling Journal of Comparative Physiology B 170: 245-251.

Ponzio, M., S. L. Monfort, J. M. Busso, V. G. Dabbene, R. D. Ruiz, $\mho$ M. Fiol De Cuneo. 2004. A non-invasive method for assessing adrenal activity in the chinchilla (Chinchilla lanígera). Journal of Experimental Zoology 301A:218-227.

Price, E. R., A. Brun, E. Caviedes-Vidal, \& W. H. Karasov. 2015 Digestive adaptations of aerial lifestyles. Physiology 30:69-78.

Price, E. R., A. Brun, V. Fasulo, W. H. Karasov, \& E. CaviedesVIDAL. 2013. Intestinal perfusion indicates high reliance on paracellular nutrient absorption in an insectivorous bat Tadarida brasiliensis. Comparative Biochemistry \& Physiology A 164:351355.

RÅberg, L., A. L., Graham, \& A. F. Read. 2009. Decomposing health: tolerance and resistance to parasites in animals Philosophical Transactions of the Royal Society B: Biological Sciences 364:37-49.

Raño, M., C. R. Valeggia, ¿ M. M. Kowalewski. 2018. Aged blackand-gold howler monkey female (Alouatta caraya): a sign of reproductive senescence? Folia Primatologica 89:101-110.

Reeder, D. A., \& K. L. Kramer. 2005. Stress in free-ranging mammals: integrating Physiology, Ecology, and Natural History. Journal of Mammalogy 86:225-235.

Reeder, D. M., N. S. KosteczK, T. H. Kunz, \& E. P. Widmaier. 2004 Changes in baseline and stress-induced glucocorticoid levels during the active period in free-ranging male and female little brown myotis, Myotis lucifugus (Chiroptera: Vespertilionidae). General \& Comparative Endocrinology 136:260-269.

Refinetti, R. 2010. The circadian rhythm of body temperature. Frontiers in Bioscience 15:564.
Rezende, E. L., F. Bozinovic, \& T. Garland. 2004. Climatic adaptation and the evolution of basal and maximum rates of metabolism in rodents. Evolution 58:1361-1374.

Romero, L. M., \& J. M. Reed. 2005. Collecting baseline corticosterone samples in the field: is under $3 \mathrm{~min}$ good enough? Comparative \& Biochemical Physiology A 140:73-79.

Rossin, M. A., \& A. I. MAliziA. 2002. Relationship between helminth parasites and demographic attributes of a population of the subterranean rodent Ctenomys talarum (Rodentla: Octodontidae). Journal of Parasitology 88:1268-70.

Sabat, P., J. A. Lagos, \& F. Bozinovic. 1999. Test of the adaptive modulation hypothesis in rodents: dietary flexibility and enzyme plasticity. Comparative Biochemistry \& Physiology A 123:83-87.

SAPolsky, R. M., L. M. Romero, ש A. U. Munck. 2000. How do glucocorticoids influence stress responses? Integrating permissive, suppressive, stimulatory and preparative actions. Endocrine Reviews 21:55-89.

SAssi, P. L., \& A. NoviLlo. 2015. Acclimating to thermal changes: Intraspecific variation in a small mammal from the Andes Mountains. Mammalian Biology 80:81-86.

SAssi, P. L., C. E. Borghi, \& F. Bozinovic. 2007. Spatial and seasonal plasticity in digestive morphology of cavies (Microcavia australis) inhabiting habitats with different plant qualities. Journal of Mammalogy 88:165-172.

Sassi, P. L., E. Caviedes-Vidal, R. Anton, \& F. Bozinovic. 2010. Plasticity in food assimilation, retention time and coprophagy allow herbivorous cavies (Microcavia australis) to cope with low food quality in the Monte desert. Comparative Biochemistry \& Physiology A 155:378-382.

Sassi, P. L., M. F. Cuevas, J. Menéndez, \& M. A. Dacar. 2017. Feeding strategies of a small mammal (Phyllotis xanthopygus, Rodentia Cricetidae) at diverse altitudes in the Central Andes, Argentina. Ethology Ecology \& Evolution 29:351-366.

Schleich, C. E., R. R. Zenuto, \& A. P. Cutrera. 2015. Immune challenge but not dietary restriction affects spatial learning in the wild subterranean rodent Ctenomys talarum. Physiology \& Behaviour 139:150-156.

SChmidt-Nielsen, K. (ED.) 1997. Animal physiology: adaptation and environment. Cambridge University Press, Cambridge

SeItz, V. P., \& S. Puig. 2018. Aboveground activity, reproduction, body temperature and weight of armadillos (Xenarthra, Chlamyphoridae) according to atmospheric conditions in the central Monte (Argentina). Mammalian Biology 88:43-51.

Sheldon, B. C., \& S. Verhulst, S. 1996. Ecological immunology: costly parasite defences and trade-offs in evolutionary ecology. Trends in Ecology \& Evolution 11:317-321.

Sironi M. ET AL. 2015. Southern right whale mortalities at Península Valdés, Argentina: updated information for 2014-2015. $\mathrm{SC} / 66 \mathrm{~b} / \mathrm{BRG}$.

Somero, G. N. 2010. The physiology of climate change: how potentials for acclimatization and genetic adaptation will determine 'winners' and 'losers'. The Journal of Experimental Biology 213: 912-920.

Speakman, J. R., E. Król, ひ M. S. Johnson. 2004. The functional significance of individual variation in basal metabolic rate. Physiological \& Biochemical Zoology 77:900-915.

SPICER, J. I., \& K. J. GASTON (EDS.). 1999. Physiological diversity and its ecological implications. Blackwell Science; Marston Book Services, Malden, Mass. Abingdon, Oxon.

Stearns, S. C.(ED.) 1992. The evolution of life histories. Oxford University Press, London.

Stitт, J. T. 1976. The regulation of respiratory evaporative heat loss in the rabbit. The Journal of Physiology 258:157-171.

Superina M., \& G. A. JAHN. 2009. Seasonal reproduction in male pichis Zaedyus pichiy (Xenarthra: Dasypodidae) estimated by fecal androgen metabolites and testicular histology. Animal Reproduction Science 112: 283-292.

SuperinA M., \& G. A. JAHN. 2013. Effect of low-quality diet on torpor frequency and depth in the pichi Zaedyus pichiy (Xenarthra, 
Dasypodidae), a South American armadillo. Journal of Thermal Biology 38:280-285.

SuperinA, M., \& P. Boily. 2007. Hibernation and daily torpor in an armadillo, the pichi (Zaedyus pichiy). Comparative Biochemistry \& Physiology A148:893-898.

Superina, M., N. CARreño, \& G. JAhn. 2009. Characterization of seasonal reproduction patterns in female pichis Zaedyus pichiy (Xenarthra: Dasypodidae) estimated by fecal sex steroid metabolites an ovarian histology. Animal reproduction science 116:358-369.

Tachinardi, P., J. E. W. Bicudo, G. A. OdA, \& V. S. Valentinuzzi 2014. Rhythmic $24 \mathrm{~h}$ variation of core body temperature and locomotor activity in a subterranean rodent (Ctenomys aff. knighti), the Tuco-Tuco. PLoS ONE 9:e85674.

Tachinardi, P., V. S. Valentinuzzi, G. A. OdA, d C. L. Buck. 2017 The interplay of energy balance and daily timing of activity in a subterranean rodent: A laboratory and field approach. Physiological \& Biochemical Zoology 90:546-552.

TARABORELli, P. ET AL. 2017. Different responses of free-ranging wild guanacos (Lama guanicoe) to shearing operations: implications for better management practices in

Taraborelli, P., R., Ovejero, N. Schroeder, P. Moreno, P. Gregorio, \& P. Carmanchahi. 2011. Behavioural and physiological stress responses to handling in wild guanacos. Journal of Nature Conservation 19:356-362.

Thompson, S. D. 1992. Gestation and lactation in small mammals: Basal metabolic rate and the limits of energy use. Mammalian Energetics: Interdisciplinary views of metabolism and reproduction (T. E. Tomasi \& Horton, T. H., Eds.). Comstock Pub. Associates, Ithaca, N.Y.

Tomasi, T. E., \& T. H. Horton (EDS.). 1992. Mammalian energetics: interdisciplinary views of metabolism and reproduction. Comstock Pub. Associates, Ithaca, N. Y.

Tomotani, B. M., D. E. F. L. Flores, P. Tachinardi, J. D. Paliza, G. A. OdA, \& V. S. VAlentinuzzi. 2012. Field and laboratory studies provide insights into the meaning of day-time activity in a subterranean rodent (Ctenomys aff. knighti), the Tuco-Tuco. PLoS ONE 7:e37918.

Vera F. Zenuto R. \& C. D. Antinuchi. 2008. Decreased glucose tolerance but normal blood glucose levels in the field in the caviomorph rodent Ctenomys talarum: The role of stress and physical activity. Comparative Biochemistry \& Physiology A 151:232-238.

Vera, F., C. D. Antenucci, \& R. R. Zenuto. 2011a. Cortisol and corticosterone exhibit different seasonal variation and responses to acute stress and captivity in tuco-tucos (Ctenomys talarum). General \& Comparative Endocrinology 170:550-557.

Vera, F., R. R. Zenuto, C. D. Antenucci, J. M. Busso, \& R. H. MARín. 2011b. Validation of a radioimmunoassay for measuring testosterone concentrations in plasma samples of the subterranean rodent Ctenomys talarum: outstandingly-elevated level in the wild and the effect of captivity. Journal of Experimental Zoology Part A 315:572-583.

Vera, F., R. R. Zenuto, ש C. D. Antenucci. 2012. Differential responses of cortisol and corticosterone to adrenocorticotropic hormone $(\mathrm{ACTH})$ in a subterranean rodent (Ctenomys talarum). Journal of Experimental Zoology A 317: 173-184.

Vera, F., R. R. Zenuto, \& C. D. Antenucci. 2013. Seasonal variations in plasma cortisol, testosterone, progesterone and leukocyte profiles in a wild population of tuco-tucos. Journal of Zoology 289:111-118.

Vera, F., C. D. Antenucci, \& R. R. Zenuto. 2018. Different regulation of cortisol and corticosterone in the subterranean rodent Ctenomys talarum: Responses to dexamethasone, angiotensin II, potassium, and diet. General \&Comparative Endocrinology doi: 10.1016/j.ygcen.2018.05.019.

Vleck, D. 1979. The Energy Cost of Burrowing by the Pocket Gopher Thomomys bottae. Physiological Zoology 52:122-136.

VLECK, D. 1981. Burrow structure and foraging costs in the fossorial rodent, Thomomys bottae. Oecologia 49:391-396.

Weiner, J. 1992. Physiological limits to sustainable energy budgets in birds and mammals: Ecological implications. Trends in Ecology \& Evolution 7:384-388.

WEIR, B. J. 1974. Reproductive characteristics of hystricomorph rodents. The Biology of Hystricomorph Rodents. I.W. Rowlands \& B.J. Weir (eds.). London Academic Press, London. Pp. 113-130.

Wiegert, R. G. 1968. Thermodynamic Considerations in Animal Nutrition. American Zoologist 8:71-81.

WingField, J. C. 2018. Environmental endocrinology: insights into the diversity of regulatory mechanisms in life cycles. Integrative \& Comparative Biology 58:790-799.

Withers, P. C., C. E. Cooper, S. K. Maloney, F. Bozinovic, \& A. Cruz-Neto (eds.). 2016. Ecological and Environmental Physiology of Mammals. Oxford University Press, Oxford, United Kingdom.

Woodruff, J. A., E. A. Lacey, \& G. Bentley. 2010. Contrasting fecal corticosterone metabolite levels in captive and free-living colonial tuco-tucos (Ctenomys sociabilis). Journal of Experimental Zoology 313A: 498-507.

Woodruff, J. A., E. A. Lacey, G. Bentley, \& L. J. Kriegsfeld. 2013. Effects of social environment on baseline glucocorticoid levels in a communally breeding rodent, the colonial tuco-tuco (Ctenomys sociabilis). Hormones \&Behavior 64: 566-572.

Zenuto, R. R., A. I. VAsSAllo, \& C. Busch. 2001. A method for studying social and reproductive behaviour of subterranean rodents in captivity. Acta Theriologica 46:161-170.Zenuto R. R., C. D. Antinuchi, \& C. Busch. 2002a. Bioenergetics of reproduction and pup development in a subterranean rodent (Ctenomys talarum). Physiological \& Biochemical Zoology 75:469-478.

Zenuto, R. R., A. I. VAssallo, \& C. Busch. 2002. Social and reproductive behavior of the subterranean solitary rodent Ctenomys talarum (Rodentia: Ctenomyidae) in a seminatural enclosure. Revista Chilena de Historia Natural 75:165-177.

Zhang Z. Q., A. Brun, E. R. Price, A. P. Cruz-Neto, W. H. Karasov, ¿ E. CAVIEDES-VIDAL. 2015. A Comparison of mucosal surface area and villous histology in small intestines of the Brazilian freetailed bat (Tadarida brasiliensis) and the mouse (Mus musculus): Intestinal mucosal surface area of bats and mice. Journal of Morphology 276:102-108. 